\title{
Beyond Powder Kegs and Crystal Balls: Finding Meaning in the Appellate Body's Interpretation of WTO Law
}

\author{
Christian Plamenov Delev* \\ https://doi.org/10.21827/GroJIL.8.1.1-29
}

\author{
Keywords \\ LAW OF TREATIES; WTO LAW; FRAGMENTATION OF INTERNATIONAL \\ LAW
}

\begin{abstract}
This article seeks to establish the interpretative methodology used by the WTO Appellate Body and panels in deciding cases. The modern WTO dispute settlement system has been the subject of great criticism, including allegations of judicial activism and use of judicial precedent. These perspectives are founded upon a false theoretical dichotomy, whereby the WTO system is viewed either as a global constitutional system or, alternatively, that its rules are subsidiary to a host of other values and norms, including environmental protection, human rights and national regulatory choice. First, the modifications in institutional architecture under the dispute settlement system are traced and discussed. This includes an analysis of treaty changes, the organisation and structure of panels and the adoption of reports. Subsequently, an analysis of WTO/GATT jurisprudence is made to ascertain the various legal sources used, the normative hierarchy established, the application of VCLT provisions and other rules of treaty interpretation, the use of evolutionary interpretation and the significance of special rules. This Section relies on case law and academic literature. Finally, the question of the fragmentation of international law is addressed with respect to treaty interpretation. This Section analyses legal pluralist arguments, particularly by Weiler, Fischer-Lescano and Teubner and establishes legitimate responses to their arguments. Moreover, certain similarities are established with other international courts and tribunals.
\end{abstract}

\section{Introduction}

For over half a century, international trade law existed on the purlieus of international law as a system characterised by its strive to achieve trade liberalisation. While it may be acknowledged that the General Agreement on Tariffs and Trade (GATT) and, thereafter, the World Trade Organization (WTO) agreement are regarded as branches of international law in the traditional sense, ${ }^{1}$ their interpretation and application by the Appellate Body $(\mathrm{AB})$ and panels have at varying moments come under severe scrutiny for their alleged preference for trade liberalisation over other societal values, ${ }^{2}$ contribution towards global

$\mathrm{PhD}$ researcher at St Catharine's College, University of Cambridge; LLM (first class), Hughes Hall, University of Cambridge; LLB summa cum laude, University of Groningen. The author would like to thank Professor Panos Merkouris for his comments and feedback. All errors are his own.

1 Vienna Convention on the Law of Treaties (signed 24 May 1969, entered into force 27 January 1980) 1155 UNTS 331 (VCLT) Article 2(1)(a): a treaty is defined as 'an international agreement concluded between States in written form and governed by international law, whether embodied in a single instrument or in two or more related instruments and whatever its particular designation.'.

2 See, for instance, D Mayer and D Hoch, 'International Environmental Protection and the GATT: The Tuna/Dolphin Controversy' (1993) 31 American Business Law Journal 187, 215-218. 
distributive injustice, ${ }^{3}$ and judicial activism. ${ }^{4}$ Moreover, the present crisis regarding the appointment of $\mathrm{AB}$ members has been galvanised by the perception of 'disregard for the rules as set by WTO Members', a sentiment that has largely rested on the interpretation of the covered agreements. ${ }^{5}$

The many concerns voiced around establishing Members' commitments has as one of their sources the AB's interpretation of the covered agreements, which is noteworthy since the rules give significant leeway for 'reasoned judgements in confronting the endless and ever-changing ebb and flow of real facts in real cases in the real world'. ${ }^{6}$ Indeed, the applicable rules are largely founded upon the discovery of a balance between the flexibility and rigidity of WTO rules that would heed to the restriction against 'add[ing] to or diminish[ing]' rights and obligations. ${ }^{7}$ The key to finding the Members' common intent thus depends on the rules of interpretation employed within the context of the dispute settlement system. Accordingly, there is a reliance on a developmental meaning of terms in light of the relevant customary international law (CIL) rule, ${ }^{8}$ which finds its chief expression in Articles 31 to 33 of the Vienna Convention on the Law of Treaties (VCLT). ${ }^{9}$

The conclusion that WTO law is a self-contained system possessing constitutional significance within the international legal order has been a heartstring for both academic and political criticism of the $\mathrm{AB} .{ }^{10}$ This has largely been expressed in the theory that the WTO broadly constitutes an independent form of global governance through its 'institutional architecture', the establishment of 'normative commitments' and a gradual adjudicative process of constitutional norm creation. ${ }^{11}$ While these points have themselves been met with criticism for their wild extrapolations and implications, ${ }^{12}$ the main alternative proposed is equally unsatisfactory. Indeed, the notion that the WTO system relies on 'subsidiarity', namely 'deference to non-WTO international institutions and norms' as well as to 'substantive domestic regulatory choices', is equally incorrect in

3 M Lennard, 'Navigating by the Stars: Interpreting the WTO Agreements' (2002) 5(1) JIEL 17.

4 J Bhagwati, 'After Seattle: Free Trade and the WTO' in RB Porter et al (eds), Efficiency, Equity, and Legitimacy: The Multilateral Trading System at the Millennium (Brookings Institution Press 2001) 60-61.

5 United States Trade Representative, 'The President's Trade Policy Agenda' (March 2018) <ustr.gov/sites/default/files/files/Press/Reports/2018/AR/2018\%20Annual\%20Report\%20I.pdf> accessed 8 February 2019, 22-24.

6 Japan - Taxes on Alcoholic Beverages (Japan - Alcoholic Beverages II) (4 October 1996) WT/DS8/AB/R, $\mathrm{WT} / \mathrm{DS} 10 / \mathrm{AB} / \mathrm{R}$ and WT/DS11/AB/R, 122-123.

7 Dispute Settlement Rules: Understanding on Rules and Procedures Governing the Settlement of Disputes, Marrakesh Agreement Establishing the World Trade Organization, Annex 2 (1994) 1869 UNTS 401 (DSU) Article 3.2.

8 ibid.

9 See, for instance, United States - Standards for Reformulated and Conventional Gasoline - Status Report by the United States (US - Gasoline) (29 April 1996) WT/DS2/AB/R, 17; and Japan - Alcoholic Beverages II (n 6) 5 concerning Article 31 VCLT; EC - Customs Classification of Certain Computer Equipment (5 June 1998) WT/DS62/AB/R, WT/DS67/AB/R and WT/DS68/AB/R concerning Article 32 VCLT; for the CIL status of the VCLT, see Case Concerning Kasikili/Sedudu Island (Botswana v Namibia) [1999] ICJ Rep 1045 [18]. One must note that CIL rules may develop independently of treaty provisions giving them expression, per Case Concerning Military and Paramilitary Activities in and against Nicaragua (Nicaragua $v$ USA) (Military and Paramilitary Activities) (Merits) [1986] ICJ Rep 14 [176]-[178].

10 See, for instance, GR Shell, 'Trade Legalism and International Relations Theory: An Analysis of the World Trade Organization' (1995) 44 Duke Law Journal 829; JP Trachtman, 'The Constitutions of the WTO' (2006) 17(3) EJIL 623.

11 JL Dunoff, 'Constitutional Conceits: The WTO's 'Constitution' and the Discipline of International Law' (2006) 17(3) EJIL 648, 651-656.

12 ibid 648-650, 657-661; R Howse and K Nicolaidis, 'Enhancing WTO Legitimacy: Constitutionalization or Global Subsidiarity?' (2003) 16(1) Governance 73, 74-86. 


\section{Beyond Powder Kegs and Crystal Balls: Finding Meaning in the Appellate Body's Interpretation of WTO Law 3}

understating the significance of trade liberalisation provisions and leading to a fundamental misreading of WTO/GATT jurisprudence. ${ }^{13}$ Moreover, both perspectives have helped shape a dangerous bifurcation that the WTO legal order is either a constitutionally distinct legal order somewhat akin to the European Union or, alternatively, deferential to other international institutions and national regulations, even to the extent that its rules are 'not simply "binding" in the traditional sense'. ${ }^{14}$ This would logically result in WTO rules and, by implication, their judicial interpretations themselves becoming the subject of such a false dichotomy: either exerting some configuration of supremacy, or otherwise existing in a constant state of irregular fluctuation relative to national and international norms and rules.

This article attempts to answer the question: What are the key characteristics of the AB's approach to interpreting WTO law? The consequent analysis relies on an evaluation of the dispute settlement system and WTO/GATT jurisprudence. Moreover, by applying the international community theoretical model, which holds that the international community has become ever more integrated, enabling the creation of 'a set of overarching and hierarchically ordered principles and rules' ${ }^{15}$ it contributes to the debate on the fragmentation of international treaty interpretation by presenting the case for the congruence of the AB's approach with those of other international courts and tribunals, contra hermeneutic legal pluralism. ${ }^{16}$

The first Section analyses developments in the dispute settlement system, from the informal GATT structure to the present, highly institutionalised, dispute settlement system. Subsequently, the second Section takes two considerations into account - the types of sources of WTO law and the particular interpretative methodology established by the $\mathrm{AB}$ and panels. First, a clear dichotomy of the different sources is established. Secondly, the AB's hermeneutic methodology is described, with a focus on the following factors: the use of the general rule on treaty interpretation and other VCLT provisions; establishing Members' common intentions; the use of evolutionary treaty interpretation; the role of special rules on treaty interpretation; and the normative hierarchy established by the $A B$ and panels. The final Section considers the broader discussion on the fragmentation of

13 See, for instance, BJ Condon, 'Climate Change and Unresolved Issues in WTO Law' (2009) 12(4) JIEL $895,907-908$.

14 J Bello, 'The WTO Dispute Settlement Understanding: Less is More' (1996) 90 AJIL 416, 416; for a description of the Bello-Jackson debate, see J Pauwelyn, Conflict of Norms in Public International Law: How WTO Law Relates to other Rules of International Law (CUP 2003) 26-28.

15 A Bianchi, International Law Theories: An Inquiry into Different Ways of Thinking (OUP 2016) 49; this perspective was classically identified and developed in the works of Bruno Simma, whose main conclusion has been that the international community has performed and experienced significant developments since the once prominent focus on bilateralism and State-centred consent. Consequently, the present international legal regime has experienced a degree of 'verticalization' and seen 'the emergence of an international community, perceived as a legal community', inter alia, thus contributing to the birth of 'a true public international law'. Nonetheless, this universalist view does not necessarily extend towards the notion of international legal 'constitutionalization'. See B Simma, 'Universality of International Law from the Perspective of a Practitioner' (2009) 20(2) EJIL 265, 268; See also B Simma, 'From Bilateralism to Community Interest in International Law' (1994) 250 Recueil des Cours 217.

16 Bianchi (n 15) ch 11; E McWhinney, 'The New Pluralism in International Law and Law-Making' (Audiovisual Library of International Law Lecture Series, 10 November 2009) <webtv.un.org/meetingsevents/human-rights-treaty-bodies/committee-on-economic-social-and-cultural-rights/watch/edwardmcwhinney-on-the-new-pluralism-and-international-

law/2623213860001/?term=?lanarabic\&sort=date $>$ accessed 4 January 2019; International Law Commission (ILC), 'Fragmentation of International Law: Difficulties Arising from the Diversification and Expansion of International Law' (1 May-9 June and 3 July-11 August 2006) UN Doc A/CN4/L682. 
international law with respect to treaty interpretation. Initially, the chief contentions developed by international legal pluralists are outlined. Subsequently, legitimate normative counterarguments in favour of the international community theory are established. Finally, following discussion on the drafting of the present rules on treaty interpretation, a series of similarities between international courts and tribunals is drawn, based on comparative literature and judicial decisions.

\section{The Evolution of Dispute Settlement}

\section{A. GATT Dispute Settlement}

Interpretation under the GATT system had largely relied on, and been informed by, the relevant institutional architecture of the dispute settlement system. With the creation of the GATT after the failed International Trade Organization project, the GATT dispute settlement system was tasked with ensuring the sustained integrity of both the negotiated concessions and general rules. ${ }^{17}$ These duties were closely linked to the Contracting Parties' own obligations to publish all relevant '[1]aws, regulations, judicial decisions and administrative rulings of general application' and enforce international treaties 'affecting international trade policy ${ }^{18}$ to the utmost extent. ${ }^{19}$ This system operated on the basis of requests for consultations under Article XII or, alternatively, resolution under Article XIII GATT that led to recommendations and even the suspension of concessions.

Unlike later institutional developments, the primary obligation for organising dispute settlement rested with the Contracting Parties themselves. As Pescatore notes, 'everything [...] had to be created ex nihilo by necessity and by experience' since no structure had been laid out in the GATT itself. ${ }^{20}$ Initially, either the Contracting Parties issued resolutions or the Chairman was tasked with answering questions directed to him. ${ }^{21}$ Subsequently, a working party model was established, whereby disputants and interested parties met, in a process akin to conciliation, to discuss issues and establish findings that were then issued in a report to the Contracting Parties. ${ }^{22}$ This approach had been maintained up until 1952, when panels were first introduced in the Germany - Sardines dispute. $^{23}$

The introduction of panels had nonetheless been consistent with the nature of Article XIII GATT, since they were established by the Contracting Parties and, subsequently, their reports gained binding force only following adoption by the

17 C Thomas, 'Litigation Process under the GATT Dispute Settlement System: Lessons for the World Trade Organization?' (1996) 30(2) JWT 53, 54.

18 General Agreement on Tariffs and Trade (adopted 30 October 1947, entered into force 1 January 1948) 1950 UNTS 188, Article X.

19 Thomas (n 17) 55; Understanding Regarding Notification, Consultation, Dispute Settlement and Surveillance (28 November 1979) BISD 26S/210, para 3.

20 P Pescatore, 'The GATT Dispute Settlement Mechanism: Its Present Situation and its Prospects' (1993) 10(1) Journal of International Arbitration 5, 5.

21 ibid.

22 ibid 6; Hudec has described this process as having 'almost always assured a divided report over contested issues' - see R Hudec, Enforcing International Trade Law: The Evolution of the Modern GATT System (Butterworths 1993) 30.

23 Treatment by Germany of Imports of Sardines (1952) BISD 1S/53; Hudec explains this by referring to the fact that this early arbitration-like procedure made sense as most GATT members were 'not large enough to resort to power as an alternative.' - see Hudec (n 22) 30. 


\section{Beyond Powder Kegs and Crystal Balls: Finding Meaning in the Appellate Body's Interpretation of WTO Law 5}

Contracting Parties based on the positive consensus rule. ${ }^{24}$ However, formal rules were laid down only during the 1979 Tokyo Round, with the adoption of the Understanding Regarding Notification, Consultation, Dispute Settlement and Surveillance. ${ }^{25}$ According to the Understanding, panels were established to issue a report 'to assist' the Contracting Parties in resolving a matter. ${ }^{26}$ Prior to its adoption, this merely held the status of an 'advisory opinion'. ${ }^{27}$ Moreover, a degree of clarity had been reached concerning treatybased remedies available to the Contracting Parties. ${ }^{28}$

The relationship between the dispute settlement system's institutional architecture and its approach to handling cases is a widely known and widely discussed phenomenon. ${ }^{29}$ Primarily, the positive consensus rule served as an incentive for modifying panels' approaches in interpreting relevant rules. This resulted in the panels trying to solicit for the Contracting Parties' approval by interpreting the rules in a manner that would be convenient for resolving a particular dispute without otherwise risking express discontent from the losing party. Hudec is forthright on this: ${ }^{30}$

Legal rulings were drafted with an elusive diplomatic vagueness. They often expressed an intuitive sort of law based on shared experiences and unspoken assumptions. Because of policy cohesion within this community, the rate of compliance with these rather vague rulings was rather high.

While the question of blockage has gained considerable focus, arguments have been presented to illustrate why this may, within limits, misreport the underlying reasons for the system. Vis-à-vis the determination of cases of violation, panels did not represent all the Contracting Parties and, since reports could have unconsciously constituted new obligations, any decision required explicit consent for it to become binding. ${ }^{31} \mathrm{By}$ acknowledging that no real mechanism existed to alleviate the problem of new obligations being read into the GATT, and the contemporaneous support for a negotiation-based system as found in early GATT dispute settlement, one could understand why the panels

24 The positive consensus rule signifies that panel reports only gain legitimacy after being accepted by all the Contracting Parties on the basis of a one-State-one-vote principle. However, this incipient model faced heavy difficulties during the 1960s that resulted in high profile cases, first by Uruguay against developed countries and, subsequently, by the United States against the European Community in the so-called 'Chicken Wars', which resulted in both the European Community and the United States becoming proponents of 'the new doctrine of anti-legalism' during the late 1960's. It was only later that, preceding the Tokyo Round, the faults of the system were exposed in a number of high-profile cases, particularly between the United States and European Community; Hudec (n 22) 31-34, 38-40.

25 Understanding Regarding Notification, Consultation, Dispute Settlement and Surveillance (28 November 1979) L/4907 (Understanding).

26 ibid para 10.

27 ibid Annex, para 6(i).

28 Should a report have been adopted by the Contracting Parties, then, in the event of the losing party's noncompliance with the recommendations 'within a reasonable period of time', the 'contracting party bringing the case' could have requested an 'appropriate remedy', including suspending concessions - ibid para 22 .

29 See, for instance, Thomas (n 17) 57; WJ Davey, 'Dispute Settlement in GATT' (1987) 11(1) Fordham International Law Journal 51, 94-98; I Van Bael, 'The GATT Dispute Settlement Procedure' (1988) 22(4) JWT 67, 69; R Hudec (n 22) ch 1; L Bartels, 'The Separation of Powers in the WTO: How to Avoid Judicial Activism' (2004) 53(4) ICLQ 86, passim.

30 Hudec (n 22) 12.

31 Davey (n 29) 96. 
favoured loose and permissive interpretations of the rules. ${ }^{32}$ Moreover, following a behavioural analysis, since the panel membership was chiefly composed of diplomats, the reports issued likely mirrored and reflected the Contracting Parties' shared sentiments and concerns. $^{33}$

A final factor that features in GATT dispute settlement is the apparent shift from a legalistic to a pragmatic approach to interpretation. The period preceding the formalisation of panel procedures had been characterised by continued 'anti-legalism' up until the Tokyo Round. ${ }^{34}$ This reflected the tension regarding the development of the dispute settlement system and how it potentially diminished the relevance of negotiations. The marked shift which followed in the 1980s showed greater favour for settlement proceedings and, in turn, the panel reports became 'more structured in their reasoning and evidenced more awareness about how the particular dispute under consideration related to the larger corpus of GATT jurisprudence'. ${ }^{35}$ In particular, the failed Spain - Soyabean Oil report brought into focus that 'panels were increasingly expected to present legally sound reasons for their conclusions'. ${ }^{36}$ This trend extended into the Uruguay Round and the birth of the WTO dispute settlement system.

\section{B. WTO Dispute Settlement}

The Uruguay Round fostered the most significant judicial architectonics project since the inception of the international trade system. The Marrakesh Agreement brought about a revision of the basic processes and institutions of dispute settlement while retaining influence from GATT-era panels. This is reflected in both the WTO Agreement and the Dispute Settlement Understanding (DSU). The most significant changes are highlighted infra.

The first major development in WTO dispute settlement was the establishment of the AB. Unlike the GATT panel model, the AB was introduced as the final instance court responsible for reviewing panel reports. ${ }^{37}$ Firstly, its creation served as a resolution to the early concerns of the GATT Contracting Parties regarding the threat of new obligations unwittingly being established through the approval of panel reports, since the $A B$ could review disputes and address disputing Members' concerns. Secondly, since the AB consists of permanently appointed members, its interpretation could reflect upon previous reports

32 According to Jackson, the conflict between so-called 'power oriented' and 'rule oriented' diplomacy shapes international policy and Jackson argues in favour of the latter since it presents the greatest support for individuals' interests through an independent arbiter when compared with the continuous exertion of influence by stronger States to weaker States - see JH Jackson, 'The Crumbling Institutions of the Liberal Trade System' (1978) 28 JWTL 93, 98-101.

33 R Howse, 'Adjudicative Legitimacy and Treaty Interpretation in International Trade Law: the Early Years of WTO Jurisprudence' in JHH Weiler (ed), The EU, the WTO, and the NAFTA: Towards a Common Law of International Trade? (OUP 2001) 38.

34 Thomas (n 17) 59.

35 ibid.

36 Spain-Soyabean Oil(1981) L/5142, unadopted; according to Roessler, this panel's 'legally unsustainable' reasoning over how the national treatment provision ought to be interpreted in light of its subsequent effects showed the failure of the previous 'management approach' and served to illustrate how sentiments had changed over the precise duty of panels - see F Roessler, 'The Role of Law in International Trade Relations and the Establishment of the Legal Affairs Division of the GATT' in G Marceau (ed), A History of Law and Lawyers in the GATT/WTO (CUP 2015) 165.

37 DSU (n 7) Article 17, especially 17.1, 17.6 and 17.13; as can be established from the early negotiations, the terms of its foundation considered that it would not have a prominent role - see M Cossy, 'Drafting and Applying the DSU' in G Marceau (ed), A History of Law and Lawyers in the GATT/WTO (CUP 2015) 303. 


\section{Beyond Powder Kegs and Crystal Balls: Finding Meaning in the Appellate Body's Interpretation of WTO Law 7}

and it could also interpret Members' obligations consistently, thereby establishing greater legal certainty. This is partially embodied in the overall objectives of the dispute settlement system: to provide 'security and predictability to the multilateral trade system' and to interpret Members' 'rights and obligations' ${ }^{38}$ Early discussions between Members indicated their minimalist sentiments towards the AB's functioning being restricted to correcting 'fundamentally flawed decisions' or restricting itself to reviewing only 'extraordinary cases', ${ }^{39}$ and these have partially materialised in the limitation of solely reviewing 'issues of law' ${ }^{40}$ In practice, however, 'almost seven out of ten' panel reports have been referred to the $A B{ }^{41}$

The DSU further introduced key procedural changes to the dispute settlement system, including the establishment of a clear-cut model for resolving disputes by reaching mutually agreed solutions or, alternatively, the application of substantive rules to restore the situation to its previous order and prevent further violations. ${ }^{42}$ Similarly, alternative dispute settlement procedures have been made available. ${ }^{43}$ However, by far the most drastic change to the dispute settlement procedure concerns the adoption of reports. Whereas in the GATT system, all Contracting Parties were required to explicitly approve a panel report in order for it to gain binding force, the modernised system presented a paradigm shift to the negative consensus rule. ${ }^{44}$ As there is now mounting pressure on Members not to vote against panel reports, this serves as an institutional guarantee that allows the $A B$ and panels to freely interpret the substantive rules without being subjected to an equal degree of pressure to adjust or otherwise alter their final legal rulings.

Finally, alongside the creation of the $\mathrm{AB}$ and other procedural reforms, the introduction of authoritative interpretations, which require 'a three-fourths majority of the Members', ${ }^{45}$ has provided Members with the power to further clarify substantive law, contrary to approaches already taken by the dispute settlement system. Unlike the role of the $A B$, this entitles Members to have a direct say in the interpretation of the covered agreements and provides an opportunity to correct any perceived misinterpretations without the risk of leaving disputes unresolved. Its particular role and function are further discussed infra.

Although many changes were adopted during the Uruguay Round, a number of hallmarks of GATT dispute settlement survived the 1994 restructuring process. Resulting from the previous 'uneasy compromise' ${ }^{46}$ one of the legacies of the earlier GATT system

38 DSU (n 7) Article 3.2.

39 T Stewart (ed), The GATT Uruguay Round: A Negotiating History (1986-1992), Volume II (Kluwer 1993) 2767-2768.

$40 \quad$ DSU (n 7) Article 17.6.

41 P Van den Bossche and W Zdouc, The Law and Policy of the World Trade Organization (4th edn, CUP 2017) 278.

42 DSU (n 7) Articles 3.6, 3.7; for an overview of the procedural roadmap, see WTO, 'The Process - Stages in a typical WTO dispute settlement case' < www.wto.org/english/tratop_e/dispu_e/disp_settlement_cbt_e/c6s1p1_e.htm> accessed 6 January 2019.

43 Alternative opportunities under the DSU (n 7) include conciliation, good offices, mediation (Article 5), and arbitration (Article 25).

44 According to the negative consensus rule, it is assumed that there is a consensus in the DSB unless a consensus forms against a report.

45 Marrakesh Agreement establishing the World Trade Organization (signed 15 April 1994, entered into force 1 January 1995) 1867 UNTS 154 (WTO Agreement), Article IX:2 in light of Article 3.9 DSU (n 7).

46 JH Jackson, World Trade and the Law of the GATT (Bobbs-Merrill Company 1969) 755. 
is that the dispute settlement system seeks negotiations and a 'mutually agreed solution' to be established before a case is resolved in front of a panel. ${ }^{47}$ Secondly, although the procedures in place have been altered, as described above, the legal force of a report stems from its approval by the Members through the Dispute Settlement Body (DSB). ${ }^{48}$ Thus, Members retain a highly reduced say on reports and may voice their dissent in the approval process. Thirdly, the dispute settlement system allows only for the interpretation of rights and obligations and not for their extension. ${ }^{49}$ Similarly, the composition of panels and the $\mathrm{AB}$ remains largely unchanged. ${ }^{50}$ Finally, the place of former GATT rulings in the interpretation of the covered agreements creates a bridge between the WTO dispute settlement system and its GATT precursor. ${ }^{51}$

In conclusion, the institutional framework of the dispute settlement reform has instigated a shift towards greater dispute settlement independence, interpretative cogence and coherence, including the resolution of some of the Members' earlier trepidations. This self-redefinition has nonetheless brought into focus the almost indecipherable precariousness of the dispute settlement system and its overall theoretical footing. ${ }^{52}$ Even so, the provided instrumental clues hint at how the $\mathrm{AB}$ and panels have been vastly guided to embolden their interpretation of substantive WTO law and, moreover, to do so in light of Members' broader rights and obligations. This task cannot be done eo ipso and, in interpreting provisions, the institutions must heed GATT jurisprudence and respect the leading role of the Members themselves, especially in attaining mutual satisfaction in dispute resolution. This thus forms the broad institutional cornerstone for any further investigation into judicial interpretation.

\section{A Question of Interpretation}

The interpretation of the covered agreements is the product of diplomatic craftsmanship and the subsequent interlacing of case law. The initial assessment of the dispute settlement process and its progression highlights a number of key episodes that define the variegated interpretation of the covered agreements and have brought about the characterisation of the system of international trade law as an 'abstruse admixture of law and economics'. ${ }^{53}$ The final transition that took place in the Uruguay Round marked the greatest departure from the previously self-sustaining dispute settlement system of interpretation to one that has formed broad ties to the law of treaties as applied by other international courts and tribunals. As stated in US - Gasoline, the GATT (and, accordingly, the covered agreements as a whole) are 'not to be read in clinical isolation from public international law'. ${ }^{54}$

\section{A. Sources of WTO Law}

First and foremost, the range of sources of WTO law and their effects on Members' rights and obligations must be established. Unlike in Article 38(1) of the Statute of the

47 DSU (n 7) Arts 3.6, 3.7.

48 DSU (n 7) Arts 16.4, 17.14.

49 DSU (n 7) Arts 3.4, 19.2; compare with Understanding (n 25) paras 16-18.

50 JHH Weiler, 'The Rule of Lawyers and the Ethos of Diplomats: Reflections on the Internal and External Legitimacy of WTO Dispute Settlement' (2001) 35(2) JWT 191, 202.

51 DSU (n 7) Article 3.11.

52 See, for specific discussion, Weiler (n 50) 194-207; Trachtman (n 10); G Abi-Saab, 'The Appellate Body and Treaty Interpretation' in M Fitzmaurice, $\mathrm{O}$ Elias and P Merkouris (eds), Treaty Interpretation and the Vienna Convention on the Law of Treaties: 30 Years On (Martinus Nijhoff 2010) 100-102.

53 A Cassese, International Law in a Divided World (Clarendon 1986) 316.

54 US-Gasoline (n 9) 17. 


\section{Beyond Powder Kegs and Crystal Balls: Finding Meaning in the Appellate Body's Interpretation of WTO Law 9}

International Court of Justice (ICJ Statute), ${ }^{55}$ there exists no clear categorisation of legal sources that may be relied upon. A starting point would be to understand that a large subset of sources as identified in the Dispute Settlement Understanding (DSU) and relevant WTO/GATT jurisprudence exists under the present system. The sources may be separated into two distinct functional categories: application and use. ${ }^{56}$

Predominantly, the covered agreements, namely the multilateral agreements annexed to the WTO Agreement and plurilateral agreements, remain the primary source of rights and obligations under WTO law. ${ }^{57}$ An additional source of individual Member's WTO-plus obligations would be the Accession Protocols which, following a prolonged four-staged process under Article XXII WTO Agreement, become binding on the Member concerned. ${ }^{58}$ The covered agreements are applicable sources of law, ie they serve as the only grounds for positive rights to be brought before the dispute settlement system, and panels are encumbered with reviewing whether individual requests comply 'with both the letter and the spirit of Article 6.2 of the DSU'. ${ }^{59}$ Another important point is the precise relevance of broader international treaties, as references thereto are made in several provisions of the covered agreements and, thus, under a systemic interpretation, these form part of the overarching WTO acquis. ${ }^{60}$

International agreements serve to amplify or confine the scope of WTO law. Regarding references to other international agreements in the covered agreements, certain rights and obligations may be established as long as one takes into account the specific provisions within (and the version of) the mentioned treaty. ${ }^{61}$ As Merkouris argues, by virtue of references to these precise provisions within the covered agreements, they become 'part of the corpus of the treaty being interpreted' through the principle of incorporation,

55 Statute of the International Court of Justice (signed 26 June 1945, entered into force 24 October 1945) 33 UNTS 993, Article 38(1).

56 The dichotomy between sources of application and use is a critical tool in understanding the nature of rights and obligations under WTO law. The term 'application' must be understood as referring to sources that provide direct rights and obligation to Members. In this sense, applicable sources perform a clear-cut constitutive function and, as such, any rights originating from said sources could be defended before a panel or the AB. By contrast, the term 'use' holds a much more restricted meaning and refers to sources that fulfil a hermeneutic function, ie those sources that express or clarify the intention of the Members or otherwise provide an interpretative context within which applicable WTO law must be read. Notably, both categories may coinhere vis-à-vis certain sources.

57 DSU (n 7) Article 7.2; while the former refers to treaties that are binding on all Members, including the GATT, GATS and TRIPS Agreements, amongst others, the latter category concerns additional agreements that Members may opt to adopt; there are currently two plurilateral agreements in force, namely the Agreement on Trade in Civil Aircraft (15 April 1994) LT/UR/A-4/PLURI/1, which at the time of writing has 32 signatories, and the Agreement on Government Procurement (15 April 1994) LT/UR/A-4/PLURI/2, which has 19 parties comprising 47 WTO members and 32 more Members as observers.

58 WTO Agreement (n 45) article XXII; for details on the accession process, see WTO, 'Accession to the World Trade Organization: Procedures for Negotiations under Article XII (Note by the Secretariat)' (24 March 1995) WT/ACC/1; concerning binding force, see, for instance, China-Measures Related to the Exportation of Various Raw Materials (China-Raw Materials) (30 January 2012) WT/DS394/AB/R, $\mathrm{WT} / \mathrm{DS} 395 / \mathrm{AB} / \mathrm{R}$ and WT/DS398/AB/R, para 303 on the potential scope thereof.

59 European Communities - Regime for the Importation, Sale and Distribution of Bananas (EC-Bananas III) (9 September 1997) WT/DS27/AB/R, para 145.

60 See, inter alia, General Agreement on Tariffs and Trade 1994 (15 April 1994) LT/UR/A-1A/1/GATT/1 (GATT), Article XXIV; Agreement on Trade-Related Aspects of Intellectual Property Rights (15 April 1994) LT/UR/A-1C/IP/1 (TRIPS), Articles 1.3, 2, 3.1, 9 and 30.

61 For discussion, see D Palmeter and PC Mavroidis, 'The WTO Legal System: Sources of Law' (1998) 92 AJIL 398, 409-410. 
thus being applicable in the same manner as the covered agreements. ${ }^{62}$ Likewise, other international agreements between the Members themselves should be recognised and utilised. Given the recognition of the VCLT as the relevant CIL on treaty interpretation, multilateral agreements, ${ }^{63}$ similar to the treatment of Ministerial Declarations, ${ }^{64}$ have been read in light of Article 31(3) VCLT as 'subsequent agreements'. ${ }^{65}$ The relevance attached to such determinations could indicate 'proximity' between provisions of WTO law and other international agreements, whether on a linguistic, temporal, subject-matter or shared actors/parties basis. ${ }^{66}$

CIL has provided the bedrock for significant modification to the interpretation and application of substantive law. While Article 3.2 DSU provides for substantive law to be interpreted 'in accordance with customary rules of interpretation of public international law', ${ }^{67}$ the standard practice established has expanded the scope of applicable CIL 'to the extent that the WTO treaty agreements do not "contract out" from it' ${ }^{68}$ While some authors have suggested that new rights may be generated by $\mathrm{CIL},{ }^{69}$ in part echoing the concerns of some Members,$^{70}$ it has been affirmed that customs are incapable of overriding treaty provisions and no explicit provision is made for customs to potentially constitute new rights. ${ }^{71}$ Contrary to the DSU's approach to international agreements, in EC-Biotech it was clarified that CIL must be binding on all Members, and not just the disputing parties, for it to be used in a case. ${ }^{72}$ This assessment is influential, especially in illustrating a desire to form cohesion between the law applicable to all Members and, moreover, to bridge WTO law and international law in a broader sense. This has also influenced the AB's own tendency to avoid making determinations on the status of CIL, as demonstrated in its deliberations on the precautionary principle in $E C-$ Hormones $^{73}$ Examples of situations

62 P Merkouris, Article 31(3)(c) VCLT and the Principle of Systemic Integration: Normative Shadows in Plato's Cave (Martinus Nijhoff/Brill 2015) 69.

63 United States - Import Prohibition of Certain Shrimp and Shrimp Products (US-Shrimp) (12 October 1998) WT/DS58/AB/R, paras 130-133.

64 United States - Measures Affecting the Production and Sale of Clove Cigarettes (US-Clove Cigarettes) (4 April 2012) WT/DS406/AB/R, paras 267-268; Australia - Certain Measures Concerning Trademarks, Geographical Indications and Other Plain Packaging Requirements Applicable to Tobacco Products and Packaging (AustraliaPlain Packaging) (28 June 2018) WT/DS465/23, paras 7.2409-7.2411; unlike multilateral agreements, Ministerial Declarations are chiefly regarded as falling within the scope of Article 31(3)(a) VCLT.

65 VCLT (n 1) Article 31(3)(c).

66 Merkouris (n 62) 83-95.

67 Notably, Article 17.6(ii) Agreement on Implementation of Article VI of the General Agreement on Tariffs and Trade 1994 (15 April 1994) LT/UR/A-1A/3 (Anti-Dumping Agreement) provides additional guidance that serves as a lex specialis derogation from the general rule on interpretation - see, for discussion, I Van Damme, 'Treaty Interpretation by the WTO Appellate Body' (2010) 21(3) EJIL 605, 608-610.

68 Korea-Measures Affecting Government Procurement (Korea-Procurement) (1 May 2000) WT/DS163/R, para 7.96.

69 A Davies, 'Korea-Measures Affecting Government Procurement: Some Critical Observations' (2001) 4 Public Procurement Law Review 229, 236.

70 Minutes of Meeting (19 June 2000) WT/DSB/M/84, para 64.

71 See, for example, European Communities - Measures Concerning Meat and Meat Products (Hormones) (18 August 1997) WT/DS26/R/USA, paras 8.157 and 8.160.

72 European Communities - Measures Affecting the Approval and Marketing of Biotech Products (26 September 2006) WT/DS291/R, WT/DS292/R and WT/DS293/R, para 7.68.

73 See European Community - Measures Concerning Meat and Meat Products (Hormones) (EC-Hormones) (16 January 1998) WT/DS26/AB/R and WT/DS28/AB/R, para 123 - the AB ultimately concluded by stating: 'We consider, however, that it is unnecessary, and probably imprudent, for the Appellate Body in this appeal to take a position on this important, but abstract, question.' . 


\section{Beyond Powder Kegs and Crystal Balls: Finding Meaning in the Appellate Body's Interpretation of WTO Law 11}

where CIL has been applied in WTO dispute settlement include questions of standing ${ }^{74}$ and the role of municipal law in dispute settlement. ${ }^{75}$

Dispute settlement reports are of material importance to the correct interpretation of Members' obligations. While GATT panel reports are made pertinent under Article 3.1 DSU for establishing continuity between GATT and WTO dispute settlement practice, ${ }^{76}$ one must acknowledge that this only concerns adopted panel reports. ${ }^{77}$ Moreover, with respect to the significance of WTO/GATT jurisprudence, the AB acknowledged the role played by reports in creating 'legitimate expectations among WTO Members' ${ }^{78}$ especially since panels are expected to follow existing $\mathrm{AB}$ precedent. ${ }^{79}$ There is strong evidence of the continued practice of the $\mathrm{AB}$ of cross-referencing previously adopted reports. ${ }^{80}$ This interpretative synchrony between panels and the $A B$ mainly concerns the reasoning employed by panels, which some commentators have regarded as the foundation of a de facto doctrine of precedent. ${ }^{81}$

In finding fault with the panel's interpretation of Articles VI:2 GATT and 9.3 AntiDumping Agreement regarding 'simple zeroing in periodic reviews', the $\mathrm{AB}$ argued in $U S$ - Stainless Steel (Mexico) for panels to ensure 'security and predictability' by resolving similar cases the same way as the $\mathrm{AB}$, 'absent cogent reasons' ${ }^{82}$ In US-Continued Zeroing, the $\mathrm{AB}$ went as far as to definitively interpret 'dumping', despite the raging debate over the exact meaning of the term. This statement, although relating to a debate that is consigned to a special interpretative framework, ${ }^{83}$ discussed above, clearly illustrates the AB's restrictive reading of the 'absent cogent reasons' exception. Still, the only enunciation of what 'cogent reasons' entails had been set out in the US - Countervailing and Anti-Dumping Measures (China) panel report. ${ }^{84}$

A number of other subsidiary sources have been recognised as contributing to the interpretation of primary WTO law. The great plurality of sources recognised, either

74 EC-Bananas III (n 59) para 133.

75 India - Patent Protection for Pharmaceutical and Agricultural Chemical Products (India-Patents) (19 December 1997) WT/DS50/AB/R, para 65.

76 See Section 2.2 for details.

77 With respect to the shift in interpretation of Article XX(g) GATT expressed in US - Shrimp (n 63) para 121, Bhagwati, (n 4) 60-61, holds that this 'reversed long-standing jurisprudence on process and production methods'. As rightly argued by Howse, this argument could have been sound had the panel report been adopted by the Contracting Parties. Rather, the failure to adopt may be read as signifying disapproval of the former decision. However, as previously mentioned, the role of reports is merely hermeneutic and does not expand into application as herein understood - see R Howse, The WTO System: Law, Politics \& Legitimacy (Cameron 2007) 180-182.

78 Japan-Alcoholic Beverages II (n 6) 108.

79 United States - Sunset Reviews of Anti-Dumping Measures on Oil Country Tubular Goods from Argentina (29 November 2004) WT/DS68/AB/R, para 188.

80 J Pauwelyn, 'Minority Rules: Precedent and Participation Before the WTO Appellate Body' in J Jemielniak, L Nielsen and HP Olsen (eds), Establishing Judicial Authority in International Economic Law (CUP 2015) 142-144.

81 See, for instance, JH Jackson, Sovereignty, the WTO, and Changing Fundamentals of International Law (CUP 2006) 151; Palmeter and Mavroidis (n 61) 401.

82 United States - Final Anti-Dumping Measures on Stainless Steel from Mexico (US - Stainless Steel (Mexico)) (30 April 2008) WT/DS344/AB/R, paras 146, 154-162.

83 United States - Continued Existence and Application of Zeroing Methodology (US - Continued Zeroing) (4 February 2009) WT/DS350/AB/R; see also comments on Anti-Dumping Agreement in footnote 70.

84 United States - Countervailing and Anti-Dumping Measures on Certain Products from China (US - Countervailing and Anti-Dumping Measures (China)) (27 March 2014) WT/DS449/R, para 7.317. 
directly or indirectly, has contributed to a hermeneutic change of heart, especially since some sources, such as teachings of the most highly qualified publicists, had only rarely been recognised by GATT-era panels, contrary to their present, rising, use ${ }^{85}$ Other sources that have been used or alluded to in applying the relevant rules include Ministerial Decisions and Declarations, ${ }^{86}$ acts of the WTO bodies, ${ }^{87}$ general principles of law, ${ }^{88}$ negotiating history, ${ }^{89}$ and 'concordant, common and consistent' subsequent practice. ${ }^{90}$ This web of sources has significantly contributed to a broader and more detailed analysis of the covered agreements, especially in forming a harmonious interpretation that is consistent with Members' common intentions.

\section{B. Method of Interpretation}

The obligation to interpret WTO law raises questions regarding which principles underpin the interpretative method established by WTO/GATT jurisprudence. The AB's approach to interpreting the covered agreements has been noted for breaking off with the 'GATT panels' ignorance of the general rules of international law' ${ }^{91}$ Reliance on the VCLT has served as the chief interpretative rule, despite not all Members being signatories to the treaty, ${ }^{92}$ and there has also been reliance on other rules. ${ }^{93}$ This sub-section describes and evaluates the use of relevant VCLT provisions, as well as some hermeneutic features that have gained particular consideration within WTO jurisprudence as potential outgrowths from the VCLT general rule of interpretation.

\section{i. Articles 31-33 VCLT}

Regarding the interpretation of treaty provisions, the first broadly distinguishable trend is prominent use of and reliance on the VCLT. Whereas the AB, in EC-Computer Equipment, stated that 'the only rules which may be applied in interpreting the meaning of a concession are the general rules of treaty interpretation set out in the Vienna Convention', ${ }^{44}$ in practice, other principles have also been applied, such as the principle of effective interpretation, discussed above. ${ }^{95}$ One possible justification for this approach is that, since not all WTO

85 Palmeter and Mavroidis (n 61) 408, particularly footnote 62.

86 See van den Bossche and Zdouc (n 41) 54 for general discussion.

87 US - Clove Cigarettes (n 64) para 260.

88 See, for instance, US - Shrimp (n 63) para 166 for good faith; United States - Transitional Safeguard Measure on Combed Cotton Yarn from Pakistan (8 October 2001) WT/DS192/AB/R, para 120 for the principle of proportionality; China - Measures Affecting Trading Rights and Distribution Services for Certain Publications and Audiovisual Entertainment Products (China - Publications and Audiovisual Products) (21 December 2009) $\mathrm{WT} / \mathrm{DS} 363 / \mathrm{AB} / \mathrm{R}$, para 411 for in dubio mitius, amongst others.

US - Countervailing and Anti-Dumping Measures (China) (n 84) para 7.286-7.290.

90 Japan-Alcoholic Beverages II (n 6) 106-107.

91 PJ Kuyper, 'The Law of the GATT as a Special Field of International Law: Ignorance, further refinement or self-contained system of international law?' (1994) 25 Netherlands Yearbook of International Law 227, 228.

92 As noted by the ICJ, a rule can subsist in the form of both a treaty provision and CIL, thus allowing for independent existence and development - see Military and Paramilitary Activities (n 9) [176]-[178].

93 See Section 3.1 for examples and an explanation based on general principles of international law and CIL.

94 EC-Computer Equipment (n 9) para 84.

95 US-Gasoline (n 9) 23; United States - Anti-Dumping Measures on Certain Hot-Rolled Steel Products from Japan (24 July 2001) WT/DS184/AB/R, para 101; for a detailed exploration of principles and their application, see HR Fabri and J Trachtman, 'Preliminary Report on the Jurisprudence of the WTO DSB' (ILA Study Group on Interpretation) <.ila-hq.org/index.php/study-groups?study-groupsID=75> accessed 16 


\section{Beyond Powder Kegs and Crystal Balls: Finding Meaning in the Appellate Body's Interpretation of WTO Law 13}

Members are parties to the VCLT, 'customary rules of interpretation' would serve as the general grounds for any further exploration. Consequently, whilst the VCLT presents the normative substratum for interpretation, other norms could be inferred or applied as long as agreement over their substance is established. ${ }^{96}$

In applying the VCLT general rule on interpretation, focus is placed on interpreting provisions 'in good faith in accordance with the ordinary meaning to be given to the terms of the treaty in their context and in the light of its object and purpose. ${ }^{97}$ This methodology serves as the collective application of three approaches, namely the textual approach, which focuses on 'the text of the treaty as the authentic expression of the intentions of the parties', the founding fathers approach, which emphasises the parties' intentions as 'a subjective element distinct from the text', and, finally, the teleological approach, which stresses '[the] declared or apparent objects and purposes of the treaty'. ${ }^{98}$ In heeding the 'expressed intention', the VCLT thus prohibits an overemphasis on individual States' expectations and seeks to strike a balance between hermeneutic consistency and flexibility. ${ }^{99}$

The approach adopted under the WTO dispute settlement system was described as 'holistic' in the US - Trade Act report, ${ }^{100}$ which signifies that there is no reliance on a singular method in establishing the correct reading of a provision, while noting that panels must first begin with a textual analysis and only subsequently refer to object and purpose. ${ }^{101}$ For instance, in determining the 'ordinary meaning' of a term, the panels or $\mathrm{AB}$ may use a dictionary as a starting point ${ }^{102}$ which carries some interpretative weight; ${ }^{103}$ however, sole reliance on a dictionary definition by a panel has been criticised since they are 'not necessarily capable of resolving complex questions of interpretation' and broader reference to the context of a particular term is thus required. ${ }^{104}$ Recourse to 'object and purpose' may

January 2019, 4-9; while Article 31(1) VCLT does incorporate the principle of effectiveness, noting the already mentioned distinct development of CIL norms from treaty provisions, the provision gives explicit 'precedence' to a textual interpretation - see A Aust, Modern Treaty Law and Practice (3rd edn, CUP 2013) 209.

96 See China-Publications and Audiovisual Products (n 88) para 411, on the discussion over in dubio mitius.

97 VCLT (n 1) Article 31(1).

98 ILC, 'Reports of the International Law Commission on the Second Part of its Seventeenth Session and on its Eighteenth Session' (1966) Yearbook of the International Law Commission v II 218.

99 M Lennard, 'Navigating by the Stars: Interpreting the WTO Agreements' (2002) 5(1) JIEL 17, 22.

100 United States - Sections 301-310 of the Trade Act of 1974 (27 January 2000) WT/DS152/R, para 7.22.

${ }^{101}$ M Fitzmaurice and P Merkouris, 'Canons of Treaty Interpretation: Selected Case Studies from the World Trade Organization and the North American Free Trade Agreement' in M Fitzmaurice, O Elias and P Merkouris (eds), Treaty Interpretation and the Vienna Convention on the Law of Treaties: 30 Years On (Martinus Nijhoff) 174; indeed, Abi-Saab has even gone as far as to label the approach 'strict constructionism' - see G Abi-Saab, 'The Appellate Body and Treaty Interpretation' in G Sacerdoti, A Yanovitch and J Bohanes (eds), The WTO at Ten - The Contribution of the Dispute Settlement System (CUP 2006) 461.

102 United States - Final Countervailing Duty Determination with respect to certain Softwood Lumber from Canada (US - Softwood Lumber from Canada) (19 January 2004) WT/DS257/AB/R, para 58.

103 European Communities - Trade Description of Sardines (26 September 2002) WT/DS231/AB/R, para 300.

104 United States - Measures Affecting the Cross-Border Supply of Gambling and Betting Services (US Gambling) (7 April 2005) WT/DS285/AB/R, para 164; see, for critical appraisal of the use of dictionaries, D Pavot, 'The Use of Dictionary by the WTO Appellate Body: Beyond the Search of Ordinary Meaning' (2014) 4(1) Journal of International Dispute Settlement 29. 
be made when the treaty terms are 'equivocal or inconclusive' since 'light from the object and purpose of the treaty as a whole may usefully be sought'. ${ }^{105}$

In determining 'context', there is a general reliance on several sources. Taking into account the wording of Article 31(2) VCLT and relevant jurisprudence, there are three broad contextual categories: other treaty provisions, agreements made in connection thereto, and instruments accepted as related. The AB specified in Korea-Dairy Products that 'a treaty should be interpreted as a whole, and, in particular, its sections and parts should be read as a whole', ${ }^{106}$ which could be taken as an intrinsic, textual application of the principle of harmonious interpretation in establishing the context of a term. ${ }^{107}$ With respect to the second and third categories, they have respectively been interpreted by the $U S$ - Copyright Act panel as 'an agreement or instrument [...] related to' a covered agreement, 'concerned with' its substance, which can 'clarify certain concepts in the treaty or limit its field of application', and which 'must [...] be drawn up on the occasion of the conclusion of the treaty'. ${ }^{108}$

Lennard has questioned the reference to 'uncontested interpretations given at a conference' as falling under Article 31(2) VCLT. ${ }^{109}$ The AB subsequently narrowed the interpretation of 'context' in US - Gambling by categorising an Explanatory Note and Classification List dating to the Uruguay Round as preparatory work. ${ }^{110}$ A key consideration of what falls under Article 31(2)(a) VCLT was provided in EC-Chicken Cuts concerning the Harmonized System Convention. ${ }^{111}$ Concerning the final category, no exact clarity has been provided by the panels or $\mathrm{AB}$. Nonetheless, as Lennard makes clear, there exists an explicit requirement that 'all' Members were involved and, consequently, Working Party Reports that have been considered, but not explicitly integrated into the agreements, would likely satisfy the requirements. ${ }^{112}$

Article 31(3) VCLT provides for certain additional aspects 'to be taken into account', namely subsequent agreements, subsequent practice, and 'any other rules of international law in the relations between the parties', which have the purpose of 'strengthening [a court or tribunal's] conclusion as to the common intention of the parties

${ }^{105}$ US - Shrimp (n 63) para 114; however, note that object and purpose may first be found in the provision itself, per Thailand - Customs and Fiscal Measures on Cigarettes from the Philippines (17 June 2011) WT/DS371/AB/R, para 202; moreover, in United States - Measures Concerning the Importation, Marketing and Sale of Tuna and Tuna Products (US - Tuna II) (16 May 2012) WT/DS381/AB/R, paras 353-379, recourse was made to the preamble of the Agreement on Technical Barriers to Trade (15 April 1994) LT/UR/A-1A/10 to establish object and purpose - see, for commentary, Y Zhang, 'Contribution of the WTO to Treaty Interpretation' in G Marceau (ed), A History of Law and Lawyers in the GATT/WTO (CUP 2015) 578-579.

${ }^{106}$ Korea - Definitive Safeguard Measure on Imports of Certain Dairy Products (12 January 2000) WT/DS98/AB/R, para 81.

${ }^{107}$ Fabri and Trachtman (n 95) 12.

${ }^{108}$ United States - Section 110(5) of US Copyright Act (15 June 2000) WT/DS160/R, para 6.45.

${ }^{109}$ Lennard (n 110) 25.

${ }^{110}$ US - Gambling (n 104) para 205.

${ }^{111}$ In European Communities - Customs Classification of Frozen Boneless Chicken Cuts (EC-Chicken Cuts) (12 September 2005) WT/DS269/AB/R and WT/DS286/AB/R, paras 194-199, the AB argued that the International Convention on the Harmonized Commodity Description and Coding System (adopted 14 June 1983, entered into force 1 January 1988) 1503 UNTS 167 (Harmonized System Convention) fell under Article 31(2)(a) VCLT because there had been reliance on it during the Uruguay Round negotiations, a decision regarding accession had been established, some of the covered agreements make direct reference to it, eg the Agreement on Agriculture, and it had been considered by the GATT Contracting Parties - for detailed discussion, see I Van Damme, Treaty Interpretation by the WTO Appellate Body (OUP 2009) 254-257.

${ }^{112}$ Lennard (n 110) 26-27. 


\section{Beyond Powder Kegs and Crystal Balls: Finding Meaning in the Appellate Body's Interpretation of WTO Law 15}

or the meaning of the treaty at the time of its conclusion. ${ }^{113}$ Subsequent agreements, which entail a consensus in idem being reached between treaty parties as to a treaty's interpretation and application, were initially determined as encompassing Ministerial Declarations, ${ }^{114}$ and similar reasoning has also been applied to committee decisions. ${ }^{115}$ Concerning Article 31(3)(b) VCLT, there are two requirements for a source to be classified as 'subsequent practice': 'a common, consistent, discernible pattern of acts or pronouncements' and that 'those acts or pronouncements must imply agreement on the interpretation of the relevant provision'. ${ }^{116}$ In $E C$-Chicken Cuts, the $\mathrm{AB}$ further clarified that for practice to be 'common, consistent, discernible', it did not need to involve all Members and, more to the point, the Ministerial Conference and the General Council should not be inferred as the 'exclusive authority' for such determinations. ${ }^{117}$ The bar for such determinations, however, has since been pushed higher to require 'overt acts'. ${ }^{118}$ Finally, with respect to Article 31(3)(c) VCLT, the panel in $E C$ - Biotech offered the first measure of clarity by accepting that the provision 'mandates' other rules to be considered 'in good faith' so as 'to settle for that interpretation which is more in accord with other applicable rules of international law' and, consequently, to avoid 'conflicts between the relevant rules'. ${ }^{119}$ Notably, this provision does not make non-WTO norms 'directly applicable', but merely allows one to 'give a proper meaning to the treaty terms at issue'. ${ }^{120}$ The $\mathrm{AB}$ has subsequently advised 'caution' on the issue of whether the rule must be espoused by all Members, noting that Article 31(3)(c) VCLT 'is considered an expression of the "principle of systemic integration".'. ${ }^{121}$

Articles 32 and 33 VCLT refer to the use of 'supplementary means of interpretation' and different language versions, respectively. ${ }^{122}$ The former is seen as a reliance on the founding fathers approach, with little clarity provided as to the scope of what 'preparatory work' or 'circumstances of conclusion' might mean, except that a broader range of sources

113 VCLT (n 1) Article 31(3); G Schwarzenberger, International Law, Volume I: International law as Applied by International Courts and Tribunals (3rd edn, Stevens \& Sons 1957) 532.

114 US - Clove Cigarettes (n 64) para 267.

115 US-Tuna II (Mexico) (n 105) paras 366-372.

116 ibid para 192.

117 EC-Chicken Cuts (n 111) para 273; as Feldman has pointed out, the AB has been rather conservative in approving or establishing subsequent practice in its jurisdiction, potentially as a result of lacking political consensus - see AM Feldman, 'Evolving Treaty Obligations: A Proposal for Analyzing Subsequent Practice Derived from WTO Dispute Settlement' (2008) 41(3) NYUJILP 655, 676.

118 Chile - Price Band System and Safeguard Measures Relating to Certain Agricultural Products (3 May 2002) $\mathrm{WT} / \mathrm{DS} 207 / \mathrm{R}$, paras 7.79 and 7.100 .

119 EC-Biotech (n 72) paras 7.69-7.70.

${ }^{120}$ S Zleptnig, Non-Economic Objectives in WTO Law: Justification Provisions of GATT, GATS, SPS and TBT Agreements, vol 1 (Nijhoff 2010) 69-70.

${ }^{121}$ European Communities and Certain Member States - Measures Affecting Trade in Large Civil Aircraft (EC-Large Civil Aircraft) (1 June 2011) WT/DS316/AB/R, para 845; the principle of systemic integration is based on the fact that treaties are 'creatures of international law', which results in their existence, operation, and scope being limited and defined accordingly since they are 'part of the international law system.' see C McLachlan, 'The Principle of Systemic Integration and Article 31(3)(c) of the Vienna Convention' (2005) 54(2) ICLQ 279, 280; in identifying the scope of the rule, Merkouris concludes that the questions of intertemporal law (ie recourse to contemporary law) and what is meant by the use of terms, such as 'parties' are the most contentious. He further identifies four considerations on the grounds of existing case law in determining whether a 'rule' may be applicable: 1) 'terminological identity or similitude', 2) 'identity or relevance of the subject-matter of regulation', 3) 'complete or partial overlap of the parties to the treaty with the parties to the dispute' and 4) 'temporal proximity'. For further discussion, see Merkouris (n 64) 18-41, 69 et seq; see also Aust (n 95) 216-217.

${ }^{122} \operatorname{VCLT}(\mathrm{n} 1)$ Articles 32 and 33. 
may be read (particularly concerning practice), the sources must precede the treaty's conclusion, and that they may only serve an auxiliary function. ${ }^{123}$ Moreover, recourse may be had to these sources only where interpretation under Article 31 leaves 'the meaning ambiguous or obscure' or causes 'manifestly absurd or unreasonable' results. ${ }^{124}$ In light of this, the WTO system has recognised that modalities papers made in the context of concessions negotiations could qualify as preparatory work. ${ }^{125}$ Similarly, regarding circumstances, pre-treaty practice, which may hold greater value as long as it reflects Members' common intentions, and even historical background, may constitute preparatory works. ${ }^{126}$ The $\mathrm{AB}$ has generally summarised its stance in $E C$-Chicken Cuts by arguing that "[a]n "event, act or instrument" may be relevant as supplementary means of interpretation [...] when it helps to discern what the common intentions of the parties were at the time of conclusion with respect to the treaty or specific provision.' ${ }^{127}$

Concerning Article 33 VCLT, the AB has, on several occasions, had recourse to different language versions of the WTO Agreement, especially since all the agreements are available in English, Spanish and French. ${ }^{128}$ Indeed, the AB has even criticised panels for not respecting the linguistic differences in the different treaty versions. ${ }^{129}$ In summarising its technique, the $\mathrm{AB}$ stipulated: 'the treaty interpreter should seek the meaning that gives effect, simultaneously, to all the terms of the treaty, as they are used in each authentic language'. ${ }^{130}$ This may well be interpreted as a reflection of the linguistic expression of 'common intent' by the Members, especially as a collective reading of the different texts and their wording could serve to establish collective meaning as etched into the WTO Agreement. ${ }^{131}$

One potential divergence from the VCLT general rule concerns authoritative interpretations. The Ministerial Conference and General Council are not bound by panel reports and may override DSB conclusions by adopting formal interpretations. In US $F S C$, the $\mathrm{AB}$ confirmed that authoritative interpretations can affect Members' rights and obligations. ${ }^{132}$ However, it remains a disputed question whether authoritative

${ }^{123}$ MM Mbengue, 'Rules of Interpretation (Article 32 of the Vienna Convention on the Law of Treaties)' (2016) 31(2) ICSID Review 388, 388-399; I Buga, The Modification of Treaties by Subsequent Practice (OUP 2018) $75-76$.

${ }^{124} \operatorname{VCLT}(\mathrm{n} 1)$ Article 32.

${ }^{125}$ European Communities - Regime for the Importation, Sale and Distribution of Bananas - Second Recourse to Article 21.5 of the DSU by Ecuador (11 December 2008) WT/DS27/AB/RW2/ECU and Corr.1; European Communities - Regime for the Importation, Sale and Distribution of Bananas - Recourse to Article 21.5 of the DSU by the United States (22 December 2008) WT/DS27/AB/RW/USA and Corr.1, para 442.

${ }^{126}$ EC-Computer Equipment (n 9) para 9293.

${ }^{127}$ EC-Chicken Cuts (n 114) para 289.

${ }^{128}$ WTO Agreement (n 45) Article XVI:6; for examples of cases, see European Communities - Antidumping Duties on Imports of Cotton Type Bed Linen from India (12 March 2001) WT/DS141/AB/R; Chile - Price Band System and Safeguard Measures Relating to Certain Agricultural Products (Chile-Price Band) (23 October 2002) WT/DS207/AB/R; European Communities - Measures Affecting Asbestos and Products Containing Asbestos (EC-Asbestos) (12 March 2001) WT/DS135/AB/R, para 91.

${ }^{129}$ Chile-Price Band (n 118) para 271.

${ }^{130}$ US - Softwood Lumber from Canada (n 102) para 59; see, for commentary, Fabri and Trachtman (n 95) 18.

${ }^{131}$ While this point is ultimately true and confirmed by case law, care should still be had for how negotiations have indeed taken place, especially since different linguistic factors could contribute to the versions not necessarily 'carry[ing] the same weight' in practice - see Aust (n 95) 226.

132 United States - Tax Treatment for "Foreign Sales Corporations" (US - FSC) (24 February 2000) WT/DS108/AB/R, paras 112-113 - in footnote 127 to the report, the AB described the exact distinction between authoritative interpretations and DSB reports and recommendations since the latter can only 


\section{Beyond Powder Kegs and Crystal Balls: Finding Meaning in the Appellate Body's Interpretation of WTO Law 17}

interpretations, in being both applied and used, could be overridden should they contravene Article 31 VCLT or established CIL. As Abbott suggests, the AB and panels could potentially argue that an authoritative interpretation exceeds the confines of their binding 'interpretative power'. ${ }^{133}$ While a restrictive reading of what an 'authoritative interpretation' means could result in Article IX:2 WTO Agreement no longer effectively fulfilling its role of pre-empting or correcting perceived hermeneutic errors in reports, it is necessary to understand both the dichotomy between authoritative interpretations and amendments ${ }^{134}$ and the controversial nature of an ultra vires determination. ${ }^{135}$ Since authoritative interpretations maintain important open questions, they could, depending on their nature, constitute a 'subsequent agreement' or even attribute a 'special meaning [...] to a term'. ${ }^{136}$

\section{ii. Common Intentions}

In discussing hermeneutic outgrowths of the VCLT provisions, a prevailing consideration that is repeated in the dispute settlement reports is the discovery of Members' common intentions. ${ }^{137}$ As such, taking into account how words have been interpreted within the WTO context, it is safe to stipulate that their own developed meaning has largely been reflective of the lex specialis nature of the covered agreements. This can be described as a congruous Wittgensteinian language game, which could be categorised as a dialect within the broader international law language. ${ }^{138}$ For instance, in the AB's interpretation of

clarify Members' rights and obligations without 'add[ing] to or diminish[ing]' them per Article 3.2 DSU. Reasoning a contrario, Members' rights could thus be changed through the adoption of authoritative interpretations.

133 FM Abbott, 'The Doha Declaration on the TRIPS Agreement and Public Health: Lighting a Dark Corner at the WTO' (2002) 5 JIEL 469, 492-493 and footnote 83 - according to Abbott, the adoption of an authoritative interpretation must be restricted by the 'text, context, object and purpose' of the treaty being interpreted in the light of the VCLT general rule and other relevant CIL.

${ }^{134}$ WTO Agreement (n 45) Article X; Ehlermann and Ehring have argued that authoritative interpretations must only be prevented from 'revising trade rules' - see, for discussion, CD Ehlermann and L Ehring, 'The Authoritative Interpretation Under Article IX:2 of the Agreement Establishing the World Trade Organization: Current Law, Practice and Possible Improvements' (2005) 8(4) JIEL 803, 810-811; another perspective has been taken by Qureshi, namely that changes to obligations derived from authoritative interpretations can only 'alter' rights and obligations, as opposed to adding or diminishing rights. This latter perspective seems to make more sense as it respects the clear division between the alteration and amendment of rights and obligations - see AH Qureshi, Interpreting WTO Agreements: Problems and Perspectives (1st edn, CUP 2006) 37-38.

135 While a determination of ultra vires would be beneficial for maintaining the difference between Articles IX:2 and X WTO Agreement, it is practically difficult for the dispute settlement system to potentially reach such a conclusion given that only Members are able to introduce disputes. Should such a determination be made in a case, then the question of interpreting Members' common intention would become problematic. As such, even an ultra vires authoritative interpretation could hold interpretative significance, however reduced - see Ehlermann and Ehring (n 134) 809.

${ }^{136}$ In accepting that authoritative interpretations are bound in their force to merely altering rights and obligations, their role as 'context' in light of Article 31(3) VCLT could lead to their binding status as subsequent agreements and, thus, show changes in the Members' common intentions. Moreover, should clarifications be provided as to the interpretation of certain terms within the covered agreements, then it is possible for a 'special meaning' to be established as long as this does not go against the text of the covered agreement itself.

137 See, inter alia, EC-Computer Equipment (n 9) para 90 and EC-Chicken Cuts (n 114) paras 262-269.

${ }^{138}$ Indeed, this may be reaffirmed as the AB's approach is generally confined to the idea that 'the meaning of a word is its use in the language' - see L Wittgenstein, GEM Anscombe (trans), Philosophical 
schedules in EC - Computer Equipment, it noted that although Members' schedules are individually binding, they ought to be interpreted to reflect the Members' 'common intentions', especially as they are products of negotiations and are integral to the GATT. ${ }^{139}$ Moreover, since legitimate expectations are produced by adopted rulings, the arguably precedential, but admittedly significant, status of the AB's reasoning 'absent cogent reasons' reaffirms the importance of finding a sole, common intention in light of its hermeneutic approach. ${ }^{140}$

One key criticism that has been levied concerns the relationship between common intentions and the interpretation of Accession Protocols. In arguing against the hermeneutic approach, Guan claims that it embodies an 'inherent judicial activism' and certain 'theoretical deficits', assertions which are based on a fundamental misunderstanding of the AB's justification. ${ }^{141} \mathrm{He}$ establishes two chief contentions, namely that 'common intentions' are 'elusive or even unattainable', as discussed below, and that there is an apparent failure by the $\mathrm{AB}$ to acknowledge 'the somewhat distinctive nature of WTO commitments and the incomplete nature of the WTO treaty framework'. ${ }^{142}$ The latter point essentially concerns the need for interpretative flexibility, since the WTO system is a constantly growing legal order. This is supposedly exemplified by the failure to acknowledge the applicability of Article XX GATT to China's Accession Protocol as a whole. ${ }^{143}$ However, even if a broad interpretation of the phrase 'integral part' had been adopted, the lack of other references such as 'consistent with the WTO Agreement' could result in those provisions not being read in light of Article XX GATT, either on the basis of the VCLT's preferred textual approach, ${ }^{144}$ or, alternatively, by employing the expressio unius principle. ${ }^{145}$ A converse decision in China - Raw Materials would result in the AB disregarding its obligation not to create new rights or obligations. ${ }^{146}$

Investigations (2nd edn, Blackwell 1958) $21 \S 43$; this sentiment has indeed been reflected in the fact that the applicable scope of interpretation is reflective of textual evolution (see Section 3.2.iv) and, inter alia, generally prohibits unilateral meanings.

139 EC-Computer Equipment (n 9) paras 84 et seq.

140 US-Stainless Steel (Mexico) (n 81) para 160.

${ }^{141}$ W Guan, 'How General Should the GATT General Exceptions Be?: A Critique of the 'Common Intention' Approach of Treaty Interpretation' (2014) 48(2) JWT 219, 222, 231-243 - some of the points that Guan makes and that have already been touched upon herein or elsewhere include that the VCLT does not adequately reflect the law of treaties, that the $\mathrm{AB}$ has established a stare decisis principle and that the $\mathrm{AB}$ and panels exceed their interpretative competences.

142 ibid 247-248.

143 ibid 249.

144 Aust (n 94) 209.

145 Guan (n 140) 225-227; China - Raw Material (n 58) para 293.

146 On this point, the AB's reasoning has been described as following a so-called 'incorporation theory', in that only through references and cross-references could Article XX GATT be extended to the relevant provision in the Chinese Accession Protocol. In making this case, de Hoogh argues, first, that the chapeau of Article XX GATT limits the effects of the GATT provision to the agreement itself; consequently, any extension would require direct reference, which may reap troubling consequences regarding the Agreement on the Application of Sanitary and Phytosanitary Measures (SPS Agreement). Secondly, the $\mathrm{AB}$ and panel appeared to adopt 'a contrario reasoning' to a silence in the text, not an exception - see A de Hoogh, 'The Relationship between China's Protocol of Accession and the GATT 1994: China - Rare Earths and the Incorporation Theory - Off with its Head! (Part 1)' (International Economic Law and Policy Blog, 2 June 2014) <worldtradelaw.typepad.com/ielpblog/2014/06/the-relationship-between-chinasprotocol-of-accession-and-the-gatt-1994-china-rare-earths-and-the-in.html> accessed 20 May 2019; however, while accepting this criticism to an extent, two considerations must be noted: first, the SPS Agreement provisions have clearly been inspired by the text of Article XX GATT; second, while the SPS 


\section{Beyond Powder Kegs and Crystal Balls: Finding Meaning in the Appellate Body's Interpretation of WTO Law 19}

However, a particularly worrying development concerns the use of subsequent agreements. In $U S$ - Shrimp, the AB, in interpreting Article XX GATT, stipulated that the provision should be read in view of 'contemporary concerns of the community of nations about the protection of the and conservation of the environment' and had recourse to treaties that are not binding on all Members. ${ }^{147}$ While this may be possible under a broad reading of Article 31(3)(c) VCLT, it is 'not enough' for a rule to be merely binding on disputants, nor is it necessary for it to be binding on all Members; rather, 'it suffices that the rule reflects their common intentions'. ${ }^{148}$ In defending this view, Pauwelyn notes that the dispute settlement system ought first to resort to 'rules explicitly agreed to by all WTO Members', since other rules would require greater explanation in light of the issue of 'formal legitimacy' ${ }^{149}$ In accepting this admonition, the AB relied mainly on these treaties to explain the meaning of 'exhaustible natural resources' as evidence of the Members' intentions and, consequently, illustrated how the Agreement must be read as part of a broader expression by all Members of their common intentions, leading to evolutionary meanings. This therefore reaffirms that WTO law should not be deemed a separate language with its own independent expression of common intentions but is rather a dialect of the broader language of international law. ${ }^{150}$

\section{iii. Evolutionary Approach}

There are few, if any, examples of a more contentious development in WTO law than the introduction of the so-called evolutionary approach to interpretation, which lies at the heart of the ongoing judicial crisis in the $\mathrm{AB} .{ }^{151}$ The question over what sources ought to be employed, discussed above, finds at its heart the 'intertemporal knot', which concerns whether the intention of the parties is restricted to the period of treaty-making or, rather, must be viewed as constantly evolving. ${ }^{152}$ While the former approach had gained the favour of scholars like Fitzmaurice and Brownlie, and was taken in the Palmas case, ${ }^{153}$ the latter approach has found invariable support in the ICJ and European Court of Human Rights

Agreement and GATT are materially proximate, paragraph 11.3 of the Accession Protocol is distinct in that it covers exportation tariffs, a WTO-plus obligation and not importation or domestic treatment, which are the chief areas covered by the GATT. Consequently, the silence in both the text and travaux préparatoires cannot be read as extending the scope of Article XX GATT, since this would be ultra vires for the $\mathrm{AB}$ and panels to create such rights and obligations.

147 US - Shrimp (n 63) 926.

148 J Pauwelyn, 'Reply to Joshua Meltzer' (2004) 25 Mich J Int'1 L 924, 924.

149 ibid 926-927; J Meltzer, 'Interpreting the WTO Agreements - A Commentary on Professor Pauwelyn's Approach' (2004) 25 Mich J Int'1 L 917, 922; for a summary of the relevant discussion from the PauwelynMeltzer debate, see Fitzmaurice and Merkouris (n 101) 236-237.

${ }^{150}$ On this point, Wittgenstein held that having the same terminology would indicate linguistic similarity. Had it been otherwise, then, as Wittgenstein puts it: 'If a lion could talk, we could not understand him.' Wittgenstein (n 144) 224; see also, L Wittgenstein, 'Remarks on Frazer's Golden Bough' in JC Klagge and A Nordmann (eds), Philosophical Occasions (Hackett Publishing 1993) 133.

${ }^{151}$ LT Lee, 'The Legal Basis of "Evolutionary Interpretation” in the WTO Dispute Settlement' (2013) 110 통상 법률 167, 168; United States Trade Representative (n 5) 22-24.

152 C Djeffal, Static and Evolutive Treaty Interpretation: A Functional Reconstruction (CUP 2016) 172.

${ }^{153}$ G Fitzmaurice, The Law and Procedure of the International Court of Justice, volume 1 (Grotius 1986) 346; I Brownlie, Principles of Public International Law (OUP 2008) 633; Island of Palmas Case (Netherlands v USA) (1928) II RIAA 829, 845. 
(ECtHR) respectively. ${ }^{154}$ Moreover, as Djeffal has suggested, a further bifurcation may be established in how evolutionary interpretation is interpreted, namely into 'referential' and 'contential' categories, which respectively mean either that 'changing referents' impact on 'whether the meaning is tied to one certain point in time or whether it follows the course of things', or that although 'a word means something at one point in time, later the meaning is changed'. ${ }^{155}$ This must consequently be applied in the context of the AB's reports.

Evolutionary interpretation was first applied by the $\mathrm{AB}$ in the US - Shrimp case and much of the basic structure of reasoning has since fallen in line with this approach. The $\mathrm{AB}$, following a textual analysis of Article XX(g) GATT, widened its scope to discover the 'object and purpose' of the 'treaty as a whole', as discussed above. ${ }^{156}$ Moreover, within its reasoning, the $\mathrm{AB}$ relied heavily upon the 'common intentions' of the parties. In tackling the issue of whether only non-living resources would fall under 'exhaustible natural resources', following an analysis of the inconclusiveness of negotiating history and noting the changes introduced during the Uruguay Round, ${ }^{157}$ the $\mathrm{AB}$ determined that 'the generic term "natural resources" in Article XX(g) is not "static" in its content or reference but is rather "by definition, evolutionary". ${ }^{158}$ Thus, the AB had recourse to extensive non-WTO law in ascertaining a definition. ${ }^{159}$ Similar evaluations can be seen in other cases, such as China - Publications and Audiovisual Products and EC-Large Civil Aircraft. ${ }^{160}$

There are a number of points that must be taken into account with respect to this judgment and subsequent case law. Firstly, in the course of its examination of legislative history, the $\mathrm{AB}$ appears to have followed the criteria previously established in the ICJ's Namibia Opinion and, consequently, - as Lee argues - met them. ${ }^{161}$ Moreover, given the highly cautious and calculated process undertaken by the $\mathrm{AB}$ in coming to the conclusion that the 'generic term' must be defined in an 'evolutionary' manner, it is evident that such an approach is 'referential', per Djeffal's dichotomy, and, consequently, only certain broad terms that convey an intention may be interpreted in an evolutionary manner, so long as no singular, continuous meaning can be established. A third consideration concerns the broad expansiveness of when the evolutionary interpretation approach may be applied, with case law pointing to Members' schedules of commitments, ${ }^{162}$ the Subsidies and

${ }^{154}$ Djeffal (n 152) 20; for a classic statement of this view, see I Sinclair, The Vienna Convention on the Law of Treaties (2nd edn, Manchester University Press 1984) 140; for the ICJ, see Aegean Sea Continental ShelfCase (Greece v Turkey) [1978] ICJ Rep 3 [69-80]; for the ECtHR, see Matthew v UK (1999) 28 EHRR 361, para 39.

155 Djeffal (n 152) 20-21.

156 US - Shrimp (n 63) para 114.

157 ibid paras $114,128,129$.

158 ibid para 130.

${ }^{159}$ For an overview of the discussion over this determination, see the previous sub-section on 'Common Intentions'. It must be noted that while evolutionary interpretations generally require a more expansive view of public international law, this need not be so.

${ }^{160}$ China - Publications and Audiovisual Products (n 88) paras 396-397 concerning the terms 'sound recording' and 'distribution' and EC-Large Civil Aircraft (n 121) paras 844-855 concerning the term 'the parties'; for a further analysis of case law, see G Marceau, 'Evolutive Interpretation by the WTO Adjudicator' (2018) 21(4) JIEL 791, 803-810.

161 See Lee (n 155) 190-195.

162 China - Publications and Audiovisual Products (n 88) para 396; see I Willemyns, 'GATS Classification of Digital Services - Does 'The Cloud' Have a Silver Lining?' (2019) 53(1) JWT 59, 69. 


\section{Beyond Powder Kegs and Crystal Balls: Finding Meaning in the Appellate \\ Body's Interpretation of WTO Law 21}

Countervailing Measures Agreement, ${ }^{163}$ and GATT provisions, ${ }^{164}$ as subjects of evolutionary interpretation. Hence, the defining characteristic of which provisions may or may not be defined through an evolutionary interpretation depends on the terms under consideration, rather than their source.

\section{iv. Special Rules}

In considering the peculiar outgrowths of WTO law, Article 17.6(ii) Anti-Dumping Agreement provides further guidance for panels and the $A B$ in interpreting provisions within the Anti-Dumping Agreement itself. ${ }^{165}$ Supplementing Article 3.2 DSU, the interpretation of the Anti-Dumping Agreement consists of two prongs: firstly, provisions must be interpreted 'in accordance with customary rules of interpretation of public international law'; thereafter, should the panel discover 'more than one permissible interpretation', then the national measure must be viewed in light of those interpretations. ${ }^{166}$ The $\mathrm{AB}$ has thus far placed this provision within the interpretative framework of Articles 31 and $32 \mathrm{VCLT}$, meaning namely that any interpretation must be 'holistic' and the treaty term 'effective' for the interpretation to be within the 'permissible' 'interpretative range'. ${ }^{167}$

While this provision establishes the prima facie trappings of essential interpretative pluralism, Fitzmaurice and Merkouris have incisively argued that the principle of effectiveness and the VCLT rules already restrict available interpretations at the first stage. ${ }^{168}$ Indeed, given the textual tension that exists between both sentences, panels have remarkably failed to tailor their respective interpretations per this provision. ${ }^{169}$ In practice, the experienced tone-deafness on the part of panels has provoked academic dissonance and criticism. ${ }^{170}$

\section{v. Normative Reshuffling}

The final identifiable principle of treaty interpretation relates to the general dominance of WTO treaty provisions over other legal rules, particularly CIL and general principles of law, while acknowledging the balanced relationship with other international law agreements. While WTO law must be, per Peru - Agricultural Products, "interpret[ed] and appl[ied] [...] in its relationship to its normative environment' viz. "'other" international

163 United States - Tax Treatment for "Foreign Sales Corporations" - Recourse to Article 21.5 of the DSU by the European Communities (14 January 2002) WT/DS108/AB/RW, paras 142-145.

${ }^{164}$ See $E C$ - Asbestos (n 128) paras 114 and 135.

165 Anti-Dumping Agreement (n 67) Article 17.6(ii).

166 ibid.

167 US - Continued Zeroing (n 83) paras 268 and 272.

${ }^{168}$ Fitzmaurice and Merkouris (n 101) 182-190 - while noting this interpretative hurdle for greater independence, the authors still note that the reason for this interpretation rests within the second sentence. Thus, they suggest three possible approaches: the 'non-rigorous approach', which entails a less intense application of treaty interpretation rules; the 'negative approach', which excludes certain interpretations from the definition; and the 'generic approach', which entails a single, generic definition that allows for regulatory flexibility; see also M Oesch, Standards of Review in WTO Dispute Resolution (OUP 2003 ) 94.

${ }^{169}$ H Spamann, 'Standard of Review for World Trade Organization Panels in Trade Remedy Cases: A Critical Analysis' (2004) 38(3) JWT 509, 540 at footnote 144.

${ }^{170}$ For summary of this discussion, see J Greenwald, 'WTO Dispute Settlement: An Exercise in Trade Law Legislation?' (2003) JIEL 113, 115-123 - as Greenwald notes, 'in the hands of the panels and the Appellate Body, Article 17.6 has quickly become a dead letter'. However, he has agreed with some of the AB's reasoning, especially on the definition of 'zeroing'. 
law', ${ }^{171}$ and international law provisions may 'prevail over the general provisions of the Vienna Convention' when this is made possible under 'specific provisions addressing amendments, waivers, or exceptions for regional trade agreements', ${ }^{172}$ no specific provision addresses this matter with respect to other sources of international law. As such, the implications of this normative reshuffling must be given critical hermeneutic consideration in terms of the weight given to sources of law and the established role of general international law within the WTO legal system.

Concerning available remedies, Simma and Pulkowski contend that panels would first examine treaty provisions and, only subsequently, 'if this (sic) special regime proves insufficient to resolve a case', apply other rules to interpret the law. ${ }^{173}$ This has been generally justified on the grounds of WTO law, like other international legal systems, having established a lex specialis that would prevent other international legal rules, especially general principles of law and CIL, from prevailing should their provisions be excluded either explicitly or implicitly. While the argument on the grounds of lex specialis has generated some degree of criticism and the $\mathrm{AB}$ has previously referred to CIL rules on state responsibility, ${ }^{174}$ one need not readily accept Simma and Pulkowski's argument, especially in light of the principle of effective interpretation. According to Schreuer, this interpretative rule may either mean that provisions must be interpreted in a way that makes them 'meaningful' or, otherwise, in a way that provides 'maximum effect'. ${ }^{175}$ Under the former, more widely and classically accepted definition, ${ }^{176}$ only in extremis would it be possible for CIL to prevent the exclusive application of already available remedies, as by giving force to the protection of substantive rights, the exclusive nature of the DSU provisions on remedies would be lessened. Under the latter meaning, it would potentially be even more difficult to argue for the DSU provisions to lose their ingrained and intended exclusivity in the name of protecting the substantive provisions. ${ }^{177}$

171 ILC (n 16) para 423.

172 Peru - Additional Duty on Imports of Certain Agricultural Products (Peru-Agricultural Products) (20 July 2015) WT/DS457/AB/R, para 5.111; Bossche and Zdouc (n 41) 68 make reference to the issue of whether this could also expand to other non-WTO law.

173 B Simma and D Pulkowski, 'Of Planets and the Universe: Self-Contained Regimes in International Law' (2006) 17(3) EJIL 483, 488.

174 ibid 488-490; with respect to CIL on State responsibility, the AB made direct reference to ILC, 'Draft articles on Responsibility of States for Internationally Wrongful Acts, with commentaries' (2001) A/56/10, article 51 in its reasoning in United States - Definitive Safeguard Measures on Imports of Circular Welded Carbon Quality Line Pipe from Korea (15 February 2002) WT/DS202/AB/R, para 259 - this could be a potential future reference point in determining the applicability of broader CIL, particularly on State responsibility, in WTO law, in particular since the DSU provisions may be seen as having 'contract[ed] out' the Members from relying upon remedies outside of the confines of the DSU per the panel's reasoning in Korea - Procurement (n 68) para 7.96.

${ }^{175} \mathrm{CH}$ Schreuer, 'International Investment Law and General International Law - From Clinical Isolation to Systemic Integration?' in R Hofmann and CJ Tams (eds), International Investment Law and General International Law: From Clinical Isolation to Systemic Integration (Nomos 2011) 2.

${ }^{176} \mathrm{H}$ Lauterpacht, 'Restrictive Interpretation and the Principle of Effectiveness in the Interpretation of Treaties' (1947) 26 BYIL 48.

177 ibid 53 - while still a disputed topic, and noting the restrictions of general rules of law as potentially 'not the determining cause of judicial decision, but the form in which the judge cloaks a result arrived at by other means', the expressio unius est exclusio alterius rule would likely establish that the Members all knowingly consented to restrict the available gamut of remedies available to themselves. 


\section{Beyond Powder Kegs and Crystal Balls: Finding Meaning in the Appellate Body's Interpretation of WTO Law 23}

While these intrinsic secondary rules seem to be a topic of great discord within both WTO law and broader international law, ${ }^{178}$ one possible solution could well be found in the use of the principle of harmonious interpretation. The extrinsic application of this principle holds that 'an international instrument has to be interpreted and applied within the framework of the entire legal system prevailing at the time of the interpretation', ${ }^{179}$ which could be taken to mean that, while other international law norms do not per se supersede WTO law unless otherwise provided, they clearly constitute vital ingredients in the normative pool in which WTO law finds itself and could serve as either defences or interpretative considerations under, for instance, Articles 31(2) or 31(3) VCLT. However, this remains to be further addressed in WTO jurisprudence as a long-term focal point.

\section{Humpty-Dumpty in International Law}

Any discussion on the coherence of the $\mathrm{AB}$ and its approach to treaty interpretation begs an assessment of general international law and its condition. This inevitably turns the discussion towards the fragmentation of international law, a question which prompted a 2006 ILC report. ${ }^{180}$ The significance attached to this question relates to the putative creation of 'self-contained regimes', prompting 'the loss of an overall perspective on the law', even the distinct application of identical rules, and consequent international legal incoherence. ${ }^{181}$ This Section seeks to address a more restricted reading of fragmentation than the ILC report, which is understood as a conflict between general and aberrant interpretations of provisions owing to a divergence in international courts' or tribunals' perceptions, methodology and suppositions, particularly on treaty interpretation, but not resulting from express treaty deviation. ${ }^{182}$ Following the quaestio disputata model, the principal arguments for legal pluralism are first set out. Subsequently, international community theory responses, defined supra, are laid out.

\section{A. The Case for Hermeneutic Pluralism}

In endorsing differentiation in treaty interpretation, Weiler first argues that, externally, treaty interpretation is more 'indeterminate' than domestic interpretation, with a largescale culture of extrajudicial settlement and rarer contestation of judicial decisions. ${ }^{183}$ Secondly, with respect to treaty differentiation, the emergence of new treaties and treaty rules and the ever-growing range of norms and actors leads to the development of 'equally binding' and 'conflicting' legal systems with 'little horizontal coordination'. ${ }^{184}$ These factors jointly result in the emergence of two conflicting 'themes': global governance and fragmentation. These lead, inter alia, to international courts having to respect States' intentions and

${ }^{178}$ Even Pauwelyn, who advances the theory that since all WTO provisions are reciprocal they may not prevail over a WTO panel, acknowledges that they 'cannot form part of the basis of legal claims' but only serve as a 'valid legal defence': see Pauwelyn (n 14) 476.

${ }^{179}$ Legal Consequences for States of the Continued Presence of South Africa in Namibia (South West Africa) notwithstanding SC Resolution [1971] ICJ Rep 276 para 53; A McNair, The Law of Treaties (Clarendon Press 1961) 466-467.

${ }^{180}$ ILC (n 16).

181 ibid para 516.

${ }^{182}$ Unlike the report, this Section only relates to conflicts in how different provisions are interpreted and, consequently, relates to relevant general international legal rules.

183 JHH Weiler, 'Prolegomena to a Meso-theory of Treaty Interpretation at the Turn of the Century (draft article)' (International Legal Theory Colloquium, New York University School of Law, Institute for International Law and Justice, 2006) 7-12.

184 ibid 12-19. 
develop their own systems and existing inter-systemic differences when differentiating their own methods. ${ }^{185}$ Consequently, the $\mathrm{AB}$ and panels would maintain a seemingly distinct interpretative approach from other international courts and tribunals in light of their jurisdictional restrictions and the nature of their self-contained regime.

Other significant arguments have been presented. Fischer-Lescano and Teubner contend that international law faces 'polycentric globalization', which fosters 'global villages' that have themselves become 'anything but [...] harmonious' ${ }^{186}$ Consequently, the proliferation of international law into myriad areas brings to mind, to expand Abi-Saab's metaphor, 'a parasitic plant [...] seizing on all opportunities and latching onto anything that gives it the possibility of moving upwards towards the light' ${ }^{187}$ The race to expand has forced the system to 'no longer [be] structure-based', but rather become 'process-based'. ${ }^{188}$ This implies that each of the separate regimes thus becomes governed by its own legal rules that could, concerning treaty interpretation, form separate norms applicable to their specific subject-matter, especially in relation to questions of treaty conflict.

Taking these points as the chief justifications for a legal pluralist viewpoint, its normative implications require some explanation. Legal pluralism cannot be equated with the recognition that a plurality of legal sources, norms and institutions exist; on the contrary, while acknowledging that a welter of institutions and sources exist is its conditio sine qua non, legal pluralism goes beyond by challenging 'legal authority', claiming an absence of certainty over where power rests. ${ }^{189}$ Of course, the logical question that follows such a supposition is how to properly rank or order these sources and, thus, prevent conflict. No convincing answer has yet been advanced. ${ }^{190}$ Unlike Griffith's seminal observations, international law does not have as wide a variety of recognised sources comparable to national law. ${ }^{191}$ What must further be recognised, however, is that international law is a decentralised system that finds amongst its roots State voluntarism and a narrow reading of restrictions on sovereignty. ${ }^{192}$ Consequently, this position must be understood as entailing regime self-sufficiency that is, at best, only rudimentarily

185 ibid 19-23; the other conclusions drawn by Weiler are that treaty interpretation is gaining prominence and so, consequently, is scrutiny over its legitimacy; the principles of treaty interpretation 'need to be more sharply and above all explicitly defined so as to increased predictability and hermeneutic legitimacy'.

${ }^{186}$ A Fischer-Lescano and G Teubner, 'Regime-Collisions: The Vain Search for Legal Unity in the Fragmentation of Global Law' (2004) 25(4) Mich J Int'1 L 999, 1005-1006.

${ }^{187}$ G Abi-Saab, 'Fragmentation or Unification: Some Concluding Remarks' (1999) 31(4) NYUJILP 919, 931 with reference to CIL.

188 Fischer-Lescano and Teubner (n 186) 1007 - accordingly, international law is seen as deriving its uniformity from processes that 'transfer binding legality between even highly heterogeneous legal orders'however, pursuant to the authors' claims, this is not enough to inform or connect the different regimes that have formed.

189 BZ Tamanaha, 'Understanding Legal Pluralism: Past to Present, Local to Global' (2008) 30(3) SLR 375, 375.

190 ibid 387-390 for a description of the various themes and trajectories observed by distinct commentators.

191 J Griffiths, 'What is Legal Pluralism?' (1986) 24 Journal of Legal Pluralism and Unofficial Law 1, 34-35 with respect to national law; a key criticism of such internationalist implications is made in $M$ Koskenniemi, The Politics of International Law (Hart 2011) 354: 'The wider the laws grasp, the weaker their normative force. Until, finally, one becomes unable to distinguish between the gunman and the policeman, the regime of corruption from the regime of contract.'.

192 To this effect, see The Case of the SS "Lotus" (Francev Turkey) (1927) PCIJ Rep Series A No 10, 18 and Case of the SS "Wimbledon" (UK and others v Germany) (1923) PCIJ Rep Series A No 1, 25 respectively. 


\section{Beyond Powder Kegs and Crystal Balls: Finding Meaning in the Appellate Body's Interpretation of WTO Law 25}

connected to other systems and involves general international law only upon institutional collapse. ${ }^{193}$

\section{B. Hermeneutics as Rift-Stitching i. Responses to Legal Pluralism}

In answer to the arguments regarding the external issues of hermeneutics, three points can be made. Firstly, rules on treaty interpretation stemming from the VCLT and CIL have generally been espoused by most international tribunals. ${ }^{194}$ While some evident differences have come to exist, discussed below, these are generally aspects of substantive conflict that could and should be resolved through judicial dialogue based on the principle of harmonious interpretation. Consequently, international courts would be able to take the interpretative pool surrounding treaties into account when reaching their decisions. Second, contra Weiler, the mere fact that there is indeterminacy does not warrant differentiation. Rather, it could be explained by difficulty in establishing jurisdiction, the costs of litigation, or purely political concerns. ${ }^{195}$ While these two factors may be firmly interconnected, the latter does not necessarily follow from the former. Finally, there is, notably in the WTO system, certain evident hermeneutic predictability that defies Weiler's own pronouncements. ${ }^{196}$

The issue of institutional inter-relations brings to prominence the role of treaty interpretation. ${ }^{197}$ Recognising the natural limitations of recourse to general international law, it must be noted that 'self-contained regimes' ${ }^{198}$ possess unique laws that expand into specialised areas. As Higgins points out, however, this can be compared to past events including the 1970's petroleum concessions and it would be a 'flaw in logic' to expect any

193 To this effect, see A Marschik, Subsysteme im Völkerrecht: Ist Die Europäische Union Ein 'Self-Contained Regime'? (Duncker \& Humblot 1994) 162, as cited and explained in Fischer-Lescano and Teubner (n 185) 1030.

194 For an assessment of contentions over the practical value of the rules of treaty interpretation and their utility, see F Zarbiyev, 'The "Cash Value" of the Rules of Treaty Interpretation' (2018) LJIL 1; for arguments to the effect that the VCLT rules are widely accepted in international law, see Kasikili/Sedudu Island ( $\mathrm{n}$ 9) for the ICJ; see Section 3.2 for $\mathrm{AB}$ and panels; for the ICC, see D Akande, 'Sources of International Criminal Law' in A Cassese (ed), The Oxford Companion to International Criminal Justice (OUP 2009) 44-45; for the ECtHR, as a summary explanation, see LE Popa, Patterns of Treaty Interpretation as Anti-Fragmentation Tools (Springer 2018) ch 5.

195 To note the particular difficulty in distinguishing international law from international relations, see Koskenniemi (n 191) ch 15; for discussion of the practical difficulties of enforcement, see D Kritsiotis, 'International Law and the Relativities of Enforcement' in J Crawford and M Koskenniemi (eds), The Cambridge Companion to International Law (CUP 2012) 248-266.

196 To this effect, Weiler (n 183) 12 claims that if a 'strict' interpretative approach does exist, it 'should, in theory, lead to "the correct" result independently of lawyering skills'. However, as he argues, the system has provided for a 'rule of lawyers'. However, firstly, the ILC report argues against this conclusion (see ILC (n 16) para 492). Moreover, as Abi-Saab argues in light of WTO law, a practical overview of its case law would lead one to believe that the AB's approach is one of 'strict constructionism', Abi-Saab (n 101) 461 and the $\mathrm{AB}$ has itself amply argued for and largely achieved hermeneutic 'security and predictability' (see supra, particularly Section 3.2). This point is especially poignant as a counterargument, as Weiler has more recently made this very point with respect to WTO law - see Weiler (n 52) 199 et seq.

${ }^{197}$ Notably, as Koskenniemi affirms, the question of fragmentation is potently felt when there is a search for 'institutional hegemony' and rules conflict - see M Koskenniemi, The Politics of International Law (Hart 2011) 334-339; see also ILC (n 16) paras 10-15.

198 The ILC report advises against using this term since it does not accurately reflect the state of international law - see ILC (n 16) para 492. 
complete snag from general international law. ${ }^{199}$ Through treaty interpretation, international law serves to undergird many of these treaty regimes.

\section{ii. Seeds and Sprouts of Consistency}

The need for a systematic approach to treaty interpretation ultimately boils down to the guarantee of legal certainty. This may best be understood with reference to the period preceding the adoption of the VCLT provisions. During this timeframe, the level of perceived hermeneutic ambiguity had been characterised in the following bleak terms: 'a mere application of one [rule of interpretation], or a shrewd combination of two of them, may yield almost whatever conclusion the interpreter desires'. ${ }^{200}$ In light of the decentralised nature of international law, the numerous actors and rules in play, and the uneven judicialisation across sub-fields, ${ }^{201}$ the urgent need for clarity in how a consistent understanding of the 'objectivized intention of the parties' is to be reached grew immensely. ${ }^{202}$ This comprehensive obscurity had been most bluntly expressed in Lord McNair's infamous assertion: '[ $t$ ] here is no part of the law of treaties which the text-writer approaches with more trepidation than the question of interpretation' ${ }^{203}$

With this backdrop, both the Institut de Droit International (IDI) and the ILC's early discussions were centralised in achieving just this: a general approach that distributed interpretative emphasis between the textual, teleological and intention-based approaches. ${ }^{204}$ Sir Hersch Lauterpacht's critical involvement in the IDI discussion involved drawing and modifying a report on the law of treaties during the IDI's Bath and Sienna sessions that included focus on treaty parties' common intentions, regarded the treaty text as one source of discovering these intentions, and placed particular emphasis on travaux préparatoires. ${ }^{205}$ This initial emphasis was changed and, in the course of the fiery debates that took place during the Bath, Sienna, and Grenada sessions, which saw a dramatic shift when sir Gerald Fitzmaurice replaced Lauterpacht as Rapporteur, focus moved towards textualism. More attention was placed, at least in the discussions, on general rules of international law, and a significant reduction in the adopted Articles occurred, cutting their

${ }^{199}$ R Higgins, 'A Babel of Judicial Voices? Ruminations from the Bench' (2006) 55(4) ICLQ 791, 803.

200 T-C Yü, The Interpretation of Treaties (Columbia University Press 1927) 72, as cited and explained in J Stone, 'Fictional Elements in Treaty Interpretation - A Study in the International Judicial Process' (1954) 1(3) SLR 344, 344.

201 See DB Hollis, 'The Existential Function of Interpretation in International Law' in A Bianchi, D Peat and M Windsor (eds), Interpretation in International Law (CUP 2015) 80 et seq.

202 The conditions that characterised early $20^{\text {th }}$ century dispute settlement had led to interpretations 'contra legem' and a substantial decrease in legal certainty. Hence, the object of harmoniously crystallising treaty interpretation into cogent rules arose - see E Björge, 'The Vienna Rules, Evolutionary Interpretation, and the Intentions of the Parties' in A Bianchi, D Peat and M Windsor (eds), Interpretation in International Law (CUP 2015) 191, 195.

203 McNair (n 179) 364.

204 This simplification draws on the principles drawn by Fitzmaurice and de facto served to frame the debate within the IDI and ILC - see G Fitzmaurice, 'The Law and Procedure of the International Court of Justice 1951-4: Treaty Interpretation and Other Treaty Points' (1957) 33 BYIL 203, 204-209.

205 Hersch Lauterpacht's role was critical in the early IDI discussion stages, particularly in favouring the importance of reference to travaux préparatoires. This can be seen in his initial report on treaty interpretation and draft resolution, at H Lauterpacht, 'De l'Interprétation des Traités' (1950) 43(1) Annuaire de 1' Institut de Droit International, Session de Bath 366-432 and 433-434 respectively; for Lauterpacht's second report, issued during the Sienna session, see H Lauterpacht, 'De 1'Interprétation des Traités' (1952) 44(1) Annuaire de 1'Institut de Droit International, Session de Sienne 197-221. 


\section{Beyond Powder Kegs and Crystal Balls: Finding Meaning in the Appellate Body's Interpretation of WTO Law 27}

total number from six to two. ${ }^{206}$ As such, a concise set of principles and factors indicating common intentions had been accepted that would serve to establish a balanced, unitary approach to treaty interpretation. Nonetheless, while the resolution did confirm the necessary valuation in treaty interpretation, the scepticism of many IDI members in systematising all technical rules appears evident in the many principles that had been left outside the text of the resolution.

The later discussions that took place at the ILC regarding the framing and construction of the VCLT rules drew heavily on the IDI discussions, with Waldock's draft general rule 'correspond[ing] to Article 1 of the Institute's resolution' ${ }^{207}$ In doing so, the key focus of establishing a general rule of treaty interpretation developed from the earlier discussions and conclusions on treaty interpretation codification. ${ }^{208}$ By enabling the general rule to serve as a 'crucible', it thus provided legal certainty by consistently setting down what factors must be taken into account, and in what manner, when establishing the objectivised intention of the parties. ${ }^{209}$ As such, the very purpose of the general rule of interpretation has served to break with the legal uncertainty that preceded it and to lay the ground for consistent interpretation, legitimate expectations and the hermeneutic synchrony between international courts and tribunals.

Having sprouted from the early attempts to systematise treaty interpretation, the VCLT general rule of interpretation has gained prominence for its status in customary law, discussed above. Consequently, in practice, most courts respect the role of this principle with respect to their own systems, some having illustrated this in the period before VCLT's entry into force ${ }^{210}$ except where this is called for by the normative character of their subjectmatter, when justified as lex specialis. ${ }^{211}$ However, noting this limitation regarding mere intrinsic hermeneutics, several points are relevant concerning the integration of other legal sources. WTO law demonstrates how it discovered the meaning of 'evolutionary interpretation' using extrinsic sources based on Article 31(3)(c) VCLT. ${ }^{212}$ Parallels may

${ }^{206}$ For the final resolution, see IDI, 'Résolutions adoptées par l'Institut à la Session de Grenade, 11-20 avril 1956' (1956) 43(1) Annuaire de l'Institut de Droit International, Session de Grenade 358-359; for brief discussion on the sequence of events and their significance, see A Bianchi, 'The Game of Interpretation in International Law: The Players, the Cards, and Why the Game is Worth the Candle' in A Bianchi, D Peat and M Windsor (eds), Interpretation in International Law (CUP 2015) 47; concerning the role of general international law, see, for instance, P Merkouris, 'Debating the Ouroboros of International Law: The Drafting History of Article 31(3)(c)' (2007) 9(1) International Community Law Review 1, 6-11; it is further noteworthy that, whilst Lauterpacht had already noted the uselessness and potential danger of systematising technical interpretation, the final resolution went further in its reduction of the broad principles it embodies.

${ }^{207} \mathrm{H}$ Waldock, 'Third report on the Law of Treaties' (3 March, 9 June, 12 June and 7 July 1964) A/CN.4/167 and Add.1-356.

208 ILC (n 98) 219 para 8.

209 ibid.

210 Golder v UK (1975) 1 EHRR 524.

${ }^{211}$ For historical backing, this has been a point made by Fitzmaurice - see, for instance, G Fitzmaurice, 'Third Report on the Law of Treaties' (1958) A/CN.4/115 and Corr.1, 40 para 76; it is particularly relevant with respect to the ECHR and ICC, see footnote 189 for details; moreover, see Popa (n 194) 362 for further similarities in what she describes as 'overbuilding' and 'holistic' reading.

${ }^{212}$ VCLT (n 1) Article 31(3)(c) has provided for greater integration to become possible, especially given that it represents the principle of systemic integration, which has been variously regarded as grounds for the reference by international courts and tribunals to other treaty systems; however, the potential for this norm to bridging different treaty systems remains to be seen; see discussion in Section 3.2 for more detail. 
also be made with other courts. ${ }^{213}$ Rules on treaty interpretation have also prompted other similarities, particularly regarding 'supplementary means' ${ }^{214}$

Finally, interpretation could be seen as a method of resolving inter-tribunal disputes over interpretation, particularly as means of judicial dialogue and balancing. ${ }^{215}$ Singular interpretation could potentially serve as a resolution for presently conflicting interpretations, especially since, following the increase in the number of international courts and tribunals, the need for balance between different jurisdictions and norms becomes more prominent. ${ }^{216}$ By enhancing the significance of the normative environment surrounding treaty regimes, international courts may both respond to the 'insufficiencies or the perceived lack of flexibility of the general system' while accepting and relying on other regimes and employing the core hermeneutic crucible that characterises them. ${ }^{217}$

Absent great normative differentiation, and recognising treaty interpretation as an art in all but name, ${ }^{218}$ one may conclude that the $\mathrm{AB}$ and panels follow a general hermeneutic approach, particularly comparable to the ECtHR and ICJ in the highlighted ways. Moreover, the binding effect of hermeneutics extends the force of general international law, beyond serving as a court's final refuge, to an art integral to sustaining leges speciales.

\section{Conclusion}

This article has been written with the objective of describing the key characteristics of the AB's approach to interpreting WTO law. In referring to modifications to the dispute settlement system and $\mathrm{AB}$ and panel case law, as well as general international legal theory and practice, the following conclusions may be reached.

The institutional changes to the dispute settlement system have illustrated a shift from the previous tension between rule-based and power-based dispute settlement, with the former ultimately gaining favour during the Tokyo and Uruguay Rounds. The resultant WTO dispute settlement system contains certain institutional guarantees that allow for

${ }^{213}$ For the ECtHR, see Tyrer $v$ UK (1980) 2 EHRR 1, para 31; for the ICJ see Dispute Regarding Navigational and Related Rights (Costa Rica v Nicaragua) [2009] ICJ Rep 213 and Legal Consequences for States of the Continued Presence of South Africa in Namibia (South West Africa) notwithstanding SC Resolution [1971] ICJ Rep 276; see Roger Judge v Canada (13 August 2003) CCPR/C/78/D/829/1998 8 paras 10.3-10.4 for a comprehensive overview of tribunals citing WTO judgments until 2013; see G Marceau, A Izaguerri and V Lanovoy, 'The WTO's Influence on Other Dispute Settlement Mechanisms: A Lighthouse in the Storm of Fragmentation' (2013) 47(3) JWT 481.

${ }^{214}$ The ICJ does tend to develop a more restrictive reading of Article 32 VCLT, while the ECtHR and AB and panels employ this to establish greater evolutionary examinations - see Popa (n 194) 363.

${ }^{215}$ With respect to WTO-MERCOSUR relations, see Brazil - Measures Affecting Imports of Retreaded Tyres (3 December 2007) WT/DS332/AB/R, paras 226 et seq; for the relations between the now defunct NAFTA 1.0 and WTO, see NAFTA Arbitral Panel Established Pursuant to Chapter Twenty - In the Matter of Cross-Border Trucking Services (6 February 2001) Final Panel Report, Sec File No USA-MEX-98-20080-01, para 238.

${ }^{216}$ US-Gasoline (n 9) 22; for discussion, see van den Bossche and Zdouc (n 41) 547-548.

217 Simma and Pulkowski (n 173) 529.

${ }^{218}$ To this effect, see U Linderfalk, 'Is Treaty Interpretation an Art or a Science? International Law and Rational Decision Making' (2015) 26(1) EJIL 169, especially 171-175; however, taking into account the indeterminacy of science, especially given the half-life of facts, and, according to Hacking's dynamic nominalism, its potential construction of the world, see I Hacking, 'Making Up People' in T Heller et al (eds), Reconstructing Individualism (Stanford University Press 1986). One may go further and describe hermeneutics, noting the potential theoretical existence of 'pure' interpretation, as a sobering art of progressive and systemic creative moderation - see H Kelsen, Pure Theory of Law (2nd edn, University of California Press 1970) 35; however, see also R Kolb, Interprétation et création du droit international. Esquisse d'une herméneutique juridique moderne pour le droit international public (Bruylant 2006) 3 et seq. 
prior concerns to be addressed, such as the introduction of authoritative interpretations. The key enhancements affecting the liberty and congruence of dispute settlement are the negative consensus rule for report adoption and the AB's establishment. However, the DSU entails that decisions must align with previous GATT reports.

With respect to treaty interpretation, the $A B$ and panels have recognised an array of sources in previous jurisprudence, which serve the functions of application, use, or both. Alongside the adoption of a VCLT-centric approach to treaty interpretation, this has undergirded the close-knit relationship between WTO law and general international law. Indeed, in answer to the central question, the defining characteristics of WTO interpretation are its deep reliance on the VCLT as an expression of CIL alongside other rules, including the principle of effectiveness, deeply ingrained holism, textualism and reliance on external sources to establish intention, especially in establishing Members' common intentions, and the use of referential evolutionary interpretation where strict intentions cannot be established.

Finally, the question of the state of international law is important, at the very least for establishing customary rules of interpretation. In assessing the issue of the fragmentation of international law, the arguments for legal pluralism are first considered, particularly regarding the issue of indeterminacy and the lack of coordination between institutions, and the supposedly expansive spread of international law into many fields. Considering this, these assessments are disputed. Given the very nature of the VCLT's project in systematising interpretation and accepting the common hermeneutic practices shared across tribunals, the VCLT and CIL rules and principles of treaty interpretation are shown to function as means for judicial dialogue, conflict resolution and harmonisation. 